\title{
Article
}

\section{An alternative allergen risk management approach}

Manning, Louise and Soon, Jan Mei

Available at http://clok.uclan.ac.uk/14878/

Manning, Louise and Soon, Jan Mei ORCID: 0000-0003-0488-1434 (2016) An alternative allergen risk management approach. Critical Reviews in Food Science \& Nutrition . ISSN 1040-8398

It is advisable to refer to the publisher's version if you intend to cite from the work. http://dx.doi.org/10.1080/10408398.2016.1185085

For more information about UCLan's research in this area go to http://www.uclan.ac.uk/researchgroups/ and search for < name of research Group>.

For information about Research generally at UCLan please go to http://www.uclan.ac.uk/research/

All outputs in CLoK are protected by Intellectual Property Rights law, including Copyright law. Copyright, IPR and Moral Rights for the works on this site are retained by the individual authors and/or other copyright owners. Terms and conditions for use of this material are defined in the policies page.

\section{CLoK}

Central Lancashire online Knowledge www.clok.uclan.ac.uk

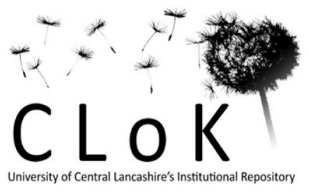




\section{Critical Reviews in Food Science and Nutrition}

\section{An alternative allergen risk management approach}

\section{Louise Manning PhD \& Jan Mei Soon}

To cite this article: Louise Manning PhD \& Jan Mei Soon (2016): An alternative allergen risk management approach, Critical Reviews in Food Science and Nutrition, DOI: 10.1080/10408398.2016.1185085

To link to this article: http://dx.doi.org/10.1080/10408398.2016.1185085

Accepted author version posted online: 31

May 2016.

Published online: 31 May 2016.

Submit your article to this journal

山 Article views: 53

Q View related articles $₫$

View Crossmark data ¿ 


\title{
ACCEPTED MANUSCRIPT
}

\section{An alternative allergen risk management approach}

Dr Louise Manning PhD (Corresponding Author)

Email: lmanning@harper-adams.ac.uk

Royal Agricultural University, School of Agriculture, Food and the Environment, Stroud Road, Cirencester, GL76JS United Kingdom of Great Britain and Northern Ireland

Dr Jan Mei Soon Email: janmei.soon@gmail.com University of central Lancashire, Preston, PR1 2SE United Kingdom of Great Britain and Northern Ireland

\begin{abstract}
Protein components in food can trigger immune-mediated response in susceptible individuals. International law requires risk assessment to be undertaken by competent individuals to minimize food safety risk to consumers. Historically, allergen control legislation has been food focused and on the requirement for on pack labeling, and the need for formal food recalls in the event of misleading or inappropriate labeling. In order to develop a mechanism for decision makers when assessing allergenic risk from plant derived materials, the aim of this research was to consider a more holistic risk assessment method whereby rather than just using the food-based approach, an additive element in terms of considering the families of proteins is included. This approach reflects the need for food professionals to fully understand the role of proteins in triggering an allergic response to plant material and the health risk to individuals who show cross-reactivity to such proteins.
\end{abstract}

\section{Keywords}

\section{Allergen, food, cross-reactivity, protein, groups, plant}




\section{ACCEPTED MANUSCRIPT}

\section{INTRODUCTION}

Allergies are usually triggered by the protein components in a food, known as allergens (Mills et al. 2003). An allergen is a compound capable of inducing a repeatable immune mediated hypersensitivity response in sensitive individuals (Mortimore and Wallace 2013:451). Adverse reaction to a food will not only include allergic reactions that are immune mediated, but also non-immune mediated reactions e.g. functional food intolerance due to enzymatic abnormalities in individuals e.g. lactase deficiency, or pharmacological reactions to amines due to excessive intake from food rich in tyramine, tryptamine, histamine and serotonin. The context for allergic reactions is complicated. Studies have investigated the connection between parasitic helminthes and expression of allergic reactions (Lynch et al. 1993; Bell, 1996). There are multiple reports on the protective contribution of helminth infections, i.e. allergic diseases appear to be rare in populations with high rates of helminth infections and common where helminth exposure is lacking or significantly reduced especially in urban areas of developing countries and industrialized nations (Cooper, 2004; Flohr et al. 2008; Smits et al. 2005; Stein et al. 2016). The "hygiene hypothesis" suggests that a lack of early childhood exposure to infectious agents, symbiotic microorganisms (e.g. gut flora) and parasites increases susceptibility to food allergy (du Toit et al. 2016). Infections with Ascaris lumbridcoides (Palmer et al. 2002) and Trucharis (Dagoyne et al. 2003) it has been suggested resulted in an increase in childhood asthma. A number of other factors such as genetic, life-cycle-phase, niche-specificity and environment (Stein et al. 2016) intensify the complexity of the association of parasitic infections with allergic disorders (Afifi et al. 2015). Other risk factors that have been postulated to be associated with food allergy include: atopic family history, gender, ethnicity, atopic dermatitis, maternal 


\section{ACCEPTED MANUSCRIPT}

ingestion during pregnancy and breastfeeding and genetic polymorphisms (du Toit et al. 2016; Lack et al. 2012).

Non-immunologically mediated reactions account for the majority of all reactions to food (Skypala, 2009; Zopf et al. 2009; Skypala, 2011). Non-immune mediated reactions to food are frequently caused by carbohydrate intolerance i.e. lactose intolerance (Lomer et al. 2008; Hammer and Hammer, 2012; Raithel et al. 2013; Wilder-Smith et al. 2013), fructose intolerance (Raithel et al. 2013; Wilder-Smith et al. 2013) and sorbitol (Born et al. 2006; Bauditz et al. 2008; Raithel et al. 2013) and reaction to biogenic amines (Jansen et al. 2003; Maintz and Novak 2007). With the exception of sulfites (Bush et al. 1986; Vally et al. 2000; Kanny et al. 2001), there are less robust studies for non-immune mediated food triggers such as food additives and chemicals (Skypala, 2009; Skypala et al. 2015).

In classical risk assessment methodology, there is some vagueness as to how allergens should be characterized. A food hazard can be defined as "a biological, chemical, or physical agent in, or condition of, food with the potential to cause an adverse health effect." (CAC, 2003:5; BS EN ISO 22000; 2005; Wallace et al. 2011:65; Manning, 2015). However the CBRI (2009) expand on this tri-categorization to include food allergens as a separate fourth category. Mortimore and Wallace (2013) use the CAC (2003) categories, but include allergens within the category of a chemical hazard. The BRC Global Standard for Food (2015:112) has refined the definition of a hazard further describing it as being "an agent of any type with the potential to cause harm (usually biological, chemical, physical or radiological". Food safety risk assessment is usually structured by defining the agent that can cause harm together with the likely foods in which it could present that harm and the controls that minimize the risk to the consumer to an acceptable 


\section{ACCEPTED MANUSCRIPT}

level. Thus food safety hazards are classified by type and their potential to cause harm in the classic hazard analysis critical control point (HACCP) approach. The challenge with classifying proteins that cause either an allergic reaction or non-immunologically mediated reaction is that these proteins do not have the potential to cause harm to all individuals and thus their presence in a food does not make that food unsafe for all, just for those that are sensitive. Mills et al. (2004) and Breiteneder and Radauer (2004) proposed alternative approaches of allergen classification as most food plant allergens belong to a small number of protein superfamilies. However, the sheer number of proteinaceous compounds that are capable of inducing an immune mediated reaction and the practical ability to consider them all in a formal risk assessment for a given product means that specialized formal allergen risk management tools are needed to assist the food scientist. In order to develop a more nuanced allergen risk assessment mechanism for decision makers that builds on existing practice, the aim of this research was to propose an additive risk assessment approach where instead of categorizing allergens only according to individual food type this is supported by considering the risk associated with cross-reactivity with the families of proteins involved.

\section{ALLERGENS: LEGISLATIVE REQUIREMENTS FOR FOOD LABELING}

The Codex Alimentarius Commission Committee on Food Labeling has listed the foods and ingredients that cause the most severe reactions and most cases of food hypersensitivity (CAC, 1985). Section 4.2.1.4 of General Standards for the Labeling of Prepackaged Foods states that "the following foods and ingredients ... shall always be declared: cereals containing gluten; i.e., wheat, rye, barley, oats, spelt or their hybridized strains and products of these; crustacea and products of these; eggs and egg products; fish and fish products; peanuts, soybeans and 


\section{ACCEPTED MANUSCRIPT}

products of these; milk and milk products (lactose included); tree nuts and nut products; and sulfite in concentrations of $10 \mathrm{mg} / \mathrm{kg}$ or more" (CAC, 1985:2). The twelve food groups currently identified in EU legislation that are required to be labeled on pre-packed food (Annex IIIa of Directive 2003/89/EC as amending 2000/13/EC) are described in Table 1. Tree nuts defined in the legislation (EC, 2003:18) include almond (Amygdalus communis L.), hazelnut (Corylus avellana), walnut (Juglans regia), cashew (Anacardium occidentale), pecan nut (Carya illinoiesis (Wangenh.) K. Koch), brazil nut (Bertholletia excelsa), pistachio nut (Pistacia vera), macadamia nut and Queensland nut (Macadamia ternifolia). This Annex has subsequently been revised by Directive 2006/142/EC with the addition of lupin and products thereof and molluscs and products thereof $(\mathrm{EC}, 2006: 110)$. The rationale behind this was the potential risk for cross allergy to lupin by those individuals who were allergic to peanuts. Molluscs were added on the basis of there being a recognized allergic reaction by some individuals to tropomyosin not only found in crustaceans and molluscs, but also in insects such as house mites and cockroaches. Additional amendment occurred in 2007 (EC 2007:13) to provide further detail on the food derivatives that required labeling but there was no further inclusion of food groups. On 25 October 2011, the European Parliament and the Council adopted Regulation (EU) No 1169/2011

on the provision of food information to consumers. This legislation requires that from the $13^{\text {th }}$ December 2014, all foods, whether packaged or sold loose, must indicate the presence of these named allergens either on pack or in the case of loose food the information must be available.

In the United States (US), the Food Allergen Labeling and Consumer Protection Act (2004) which came into force on $1^{\text {st }}$ January 2006 identifies eight major food allergens namely milk, egg, fish (e.g., bass, flounder, or cod), Crustacean shellfish (e.g., crab, lobster, or shrimp), tree 


\section{ACCEPTED MANUSCRIPT}

nuts (e.g., almonds, pecans, or walnuts), wheat, peanuts, and soybeans (FDA, 2013). Updated allergen legislation came into force in Canada on the $4^{\text {th }}$ August 2012 and identified ten "priority" allergens for labeling peanuts, tree nuts (almonds, Brazil nuts, cashews, hazelnuts, macadamia nuts, pecans, pine nuts, pistachios, walnuts), milk, eggs, seafood (fish, crustaceans, shellfish), soy, wheat, sesame seeds, mustard, sulfite (HC, nd). Food Standards Australia New Zealand (FSANZ) identify eleven allergens that they require mandatory labeling on prepacked food. The international legislative requirements for food labeling with regard to allergens have been collated (Table 1).

The table demonstrates some variation in legislative requirements across the world, with all countries using the CAC (1985) as a baseline for allergen labeling in food. The common foods defined in national legislation as requiring food labeling with regard to allergens may contain simple or multiple proteins that can cause an allergic response. For example with cow's milk nine different proteins have been identified that can cause an immune-mediated reaction; with peanuts seventeen proteins (Ara h 1 - 17) have been isolated (Table 2).

This table demonstrates the complex picture of food allergy associated with food proteins and food protein families.

\section{ALLERGENS: DETERMINING RISK FACTORS}

Food allergies affect about $10 \%$ of the Western population, where the 'big eight' allergenic food groups account for $90 \%$ of the allergic reactions that occur (van Winkle and Chang, 2014). Food allergies can be characterized by nationality and geographic variations, food availability, dietary habits, and access to foods that might cause an allergic reaction, cultural or religious obligations, hereditary and environmental factors. Cross-reactivities occur within a given food group and 


\section{ACCEPTED MANUSCRIPT}

between foods and seemingly unrelated proteins (Lehrer et al. 2009). Wallace et al. (2011:79) discuss the concept of allergenic cross-reactivity i.e. that individuals who are allergic to apples may also be allergic to birch pollen and also the regional associations with allergens e.g. EU (celery), South-east Asia (buckwheat), Japan (rice). Individuals sensitive to birch pollen have been shown to be sensitive to apples, hazelnuts, and raw vegetables such as celery and carrot (Mills et al. 2003). Shaw (2013) describes the phenomenon of cross-reactivity too with individuals who appear allergic to latex (from the rubber plant) also being highly sensitive to banana, avocado, kiwi fruit, and tomato. Cross reactivity between pollen-fruit/vegetables or latex-fruit/vegetables are examples of non-sensitizing elicitors that produce immediate symptoms after exposure (in less than an hour) usually confined to the mouth. This manifestation of cross reaction is known as oral allergy syndrome (van Ree, 1997; Hourihane, 2000). Examples of cross reactivity between pollens, fruits and vegetables have been synthesized (Table 3).

Risk assessment based on foods or ingredients that require positive labeling if they are included in the food is well developed. From an industry point of view, using the food group list and identifying regional / country's allergen labeling requirements is relatively straightforward. Labeling standards (regulatory or according to Codex guidelines) define the requirements for notification of presence, or use of the "may contain" or "free from" allergenic food groups. However, some individuals are known to show cross-reactivity to foods, and associated plant protein e.g. in pollen. Protein family-based risk assessment adds another layer of complexity and requires those undertaking risk assessment to have themselves, or have access, to expertise / knowledge in the range of known allergenic proteins and potential for cross-reactivity and the categorization of protein superfamilies and families. Why might this be of concern? Allergen 


\section{ACCEPTED MANUSCRIPT}

control procedures use strategies such as sanitation, time control of known foods or ingredients that are allergens, and designated storage or equipment. These controls would not ordinarily be adopted for foods that are not recognized in terms of allergen labeling (see Table 1), but still present a risk to the vulnerable individual. Thus, food practitioners can carry out protein-based risk assessment on existing, new or modified ingredients, food products, food contact materials, or processes. Formulation of the food products and potential allergen hazard should be listed out followed by identification and cross checking of protein superfamily among the list of allergens with the help of databases such as WHO/IUIS, Allergome, AllFam, AllergenOnline see Table 4). The use of protein-based risk assessment is discussed more fully in the section: Mechanisms for quantifying potential allergens and cross reactivity in food manufacturing.

A driver of this additive approach is the health policy consideration of personalized healthcare or personalized medicine. Kondo et al. (2014) argue that the pathogeneses and clinical features of allergies vary greatly from patient to patient meaning that the establishment of individualized therapy in the form of personalized medicine is essential. Personalized medicine has also been described as: "the use of combined knowledge (genetic or otherwise) about a person to predict disease susceptibility, disease prognosis, or treatment response and thereby improve that person's “ (Redekop and Mladsi, 2013:4). Thereby as knowledge increases as part of the responsive approach to personalized medicine treatment of food allergies should be personalized or "tailor-made" for each patient (Kondo et al. 2015). Hayes et al. (2014) determine that mobile apps are starting to be used in order to provide a personalized approach to disease management, arguing that patient-tailored risk prediction and treatment is already routinely applied at clinical level with more that needs to be done to deliver individualized treatment. 


\section{ACCEPTED MANUSCRIPT}

\section{ALLERGENS: IMMUNE MEDIATED AND NON-IMMUNE MEDIATED REACTIONS}

In this research, the focus has been on allergies to materials from plant origin only. Mills et al. (2003) proposed at the time of their writing there were 7-10 foods responsible for the majority of food allergies including those of plant origin such as peanuts, tree nuts, wheat and soy. Immune mediated reactions to food are categorized as Immunoglobulin E (IgE) mediated or non $\operatorname{IgE}$ mediated (Dean, 2000) (Figure 1). IgE is the main antibody involved in induction of rapid onset of allergic reactions and symptoms can vary from skin reactions to respiratory difficulties and anaphylactic shock. IgE mediated reaction occurs in two phases - an initial 'sensitization' to an allergen and an 'elicitation' stage (Figure 1). Sensitization occurs when an individual is exposed to the food allergen and the body produces $\operatorname{IgE}$ antibodies which bind to mast cells. $\operatorname{IgE}$ antibodies in plasma have very short life, but once bound to mast cell they can remain for months. The elicitation stage occurs upon re-exposure to the same food allergen and the $\operatorname{IgE}$ antibodies will bind to the allergen, leading to release of inflammatory molecules (e.g. histamine, cytokines, leukotrienes) and this results in allergic reaction (FDA, 2015).

Non-IgE mediated reactions are less well-studied and more difficult to diagnose. According to Venter (2009) the absence of IgE production has been well established and another class of immunoglobulin such as Immunoglobulin G (IgG) could be involved (Dean, 2000). At present, there are no known biomarkers for non-IgE mediated reaction (Nowak-Wegrzyn et al. 2015). However, Boyce et al. (2010) and Sampson et al. (2014) did not recommend diagnosing non-IgE mediated reaction by measuring food-specific $\operatorname{IgG}$ and $\operatorname{IgG}_{4}$ antibody level. Non-IgE mediated reaction involves two stages, i.e. initial and subsequent exposures (Figure 1). During the initial exposure, T-cells are sensitized by food allergens. On subsequent exposure to the same allergens, 


\section{ACCEPTED MANUSCRIPT}

the allergen will combine with the sensitized $\mathrm{T}$-cell and proceed to release inflammatory molecules such as cytokines and followed by chronic inflammation (Hamelmann and Wahn, 2002; Venter, 2009).

\section{CATEGORIZING PLANT DERIVED FOOD ALLERGENS}

Mills et al. (2003) identified the common cross-reactive food allergens that cause sensitization through inhalation (inhalation allergens) such as profilins, thaumatin like proteins, cysteine proteases, and those that sensitize via the GI tract (the prolamin and cupin superfamilies). The latter group includes the non-specific lipid transfer proteins (nsLTP), albumins, globulins, gliadins and amylase inhibitors. Proteins with residue identities of 30\% and greater or with lower sequence identities but with very similar functions and structures are categorized into families. Families whose proteins have low sequence identities, but whose structural and functional features suggest common evolutionary origin, are placed into superfamilies (Murzin et al. 1995). Radauer and Breiteneder (2007) reported that as few as 4 protein superfamilies contain nearly $60 \%$ of all plant food allergens namely prolamin (storage proteins of cereals, nsLTP, $\alpha$-amylase inhibitors, and $2 \mathrm{~S}$ albumins), cupin, (specifically the $11 \mathrm{~S}$ and $7 \mathrm{~S}$ globulin storage proteins), profilin and pathogenesis-related $(P R)$ proteins. These are now described in more detail.

\section{Prolamin superfamily}

The prolamin superfamily derives its name from proline and glutamine rich storage proteins found in cereals. It consists of six allergen families: nsLTP1, nsLTP2, 2S storage albumins, cereal $\alpha$-amylase/trypsin inhibitors, hydrophobic seed proteins and gliadin (Breiteneder and Radauer, 2004; Breiteneder and Mills, 2005; Mills et al. 2004; Radauer and Breiteneder, 2007). nsLTPs usually accumulate in the epidermal layers of plant organs thus explaining the stronger 


\section{ACCEPTED MANUSCRIPT}

allergenicity of peels compared to pulps from the Rosaseae genera i.e. apples, pears, peaches (van Ree, 2002). Despite the name, plant nsLTPs are not thought to function primarily in lipid storage instead all three groups of prolamin proteins have defensive roles against pests and pathogens (Mills et al. 2003; Egger et al. 2010; Van Winkle and Chang, 2014). As insect pests feed on crops, plants have developed a defense mechanism producing $\alpha$-amylase and protease inhibitors as part of the plant's defense system (e.g. Hor v 15 in barley). $2 \mathrm{~S}$ albumins are storage proteins present in dicotyledonous plants (Shewry et al. 1995).

\section{Cupin superfamily}

Allergenic proteins of the cupin superfamily belong to the seed storage globulins i.e. the $7 / 8 \mathrm{~S}$ globulins (vicilins) and 11S globulins (legumins) (Radauer et al. 2008). These proteins are often involved in primary food allergy with legumes, tree nuts and seeds (Mills et al. 2003). One of the major allergenic seed storage proteins in the cupin superfamily is peanut's Ara h 1 (vicilin). Ara h 1 is recognized by over $90 \%$ of the individuals allergic to peanut (Viquez et al. 2003). Crossreactivity between plant foods had been reported, for example, IgE-binding cross reactivity between peanut, lentil (Len c 1) and pea (Pis s 1) was identified (López-Torrejón et al. 2003; Wensing et al. 2003). Cross reactivity between chickpea, peas and lentils (Bar-El Dadon et al. 2014) and cross reactions between coconut and lentils (Manso et al. 2010) were also observed.

\section{Profilin family}

Profilin is a panallergen meaning allergens that share marked structural similarity and function in different species (Hauser et al. 2010; Lanida-Pineda et al. 2015) and plays a major role in polymerization of filamentous action (Carlsson et al. 1977), cell elongation, maintenance of cell shape and flowering in small flowering plants from the Arabidopsis genus (Ramachandran et al. 


\section{ACCEPTED MANUSCRIPT}

2000). They are responsible for a number of IgE cross reactions even between unrelated pollens and plant food allergens (Hauser et al. 2010).

\section{Pathogenesis-related (PR) proteins PR-10}

PRs are not a protein superfamily but represent a collection of unrelated protein families that function as part of the plant defense system (Breiteneder and Radauer, 2004). The expression of PR proteins are induced by pathogen attacks, abiotic stress or regulated during growth and development. There is a higher concentration of PR protein in reproductive tissues such as pollen, seeds and fruits (Radauer et al. 2008). Bet v 1, a major birch pollen allergen is a type of PR protein. Other plant pollens share common epitopes with Bet v 1 hence resulting in cross reactions i.e. in Rosaseae (apples, stone fruits) and Apiaceae family (celery and carrot) (Vieths et al. 2002). The cross reactions between Bet $\mathrm{v} 1$ and homologous allergen from plant foods is responsible for birch pollen-associated food allergy (Vieths et al. 2002).

This review of four protein superfamilies and families demonstrates the potential for individuals to exhibit plant-related food hypersensitivities triggered by specific proteins that are common in foods. Identifying the nature of such shared allergenic proteins will firstly inform food policy and assist in developing appropriate communication tools for individuals that demonstrate crossreactivity to these proteins and secondly aid the food industry to carry out more comprehensive allergen-based risk assessment strategies for their food products especially during product development processes.

\section{MITIGATING RISK: MANUFACTURING CONTROLS}

The use of pre-requisite programmes (PRPs) to minimize the risk of food safety incidents and food quality issues is well established in food science. These PRPs include the protocols that 


\section{ACCEPTED MANUSCRIPT}

form the basis of good manufacturing practice and they underpin the use of HACCP to risk assess potential food safety hazards, the means for their control and mitigation and the associated control plan that needs to be developed to ensure food control systems are effective. Legislation is of limited value when foods that are not declarable allergens are contaminated with extraneous plant material, pollen or protein, even at very small levels, from plants known to cause an allergic reaction e.g. kiwi hairs, peach blossom left on a conveyor belt when other fruit is then processed. Thus allergens, or proteins derived from allergenic foods, may be present in foods as the result of cross-contact during processing and handling (FDA, 2006). Cross-contact occurs when a residue or other trace amount of an allergenic food is unintentionally transferred into another food, despite good manufacturing practices (GMP) being in place (FoodDrinkEurope, 2013:26). The FDA (2006:21) states that the term cross-contact can be used to "describe the inadvertent introduction of an allergen into a product that would not intentionally contain that allergen as an ingredient". Further the report suggests that cross-contact may occur as previously described in this paper as a result of a trace amount of an allergenic protein being present on food contact surfaces, production machinery, or depending on the nature of the material (dust, solid, liquid) being air-borne, through the poor control of product rework, or ineffective cleaning and sanitization and unintentionally becomes incorporated into another product. Therefore implementing appropriate measures as part of the PRP will mitigate risk and their presence or absence should be considered as part of the risk assessment process.

The risk of cross-contact increases when multiple foods are produced in the same facility and there is shared harvest equipment, storage, transportation, or production equipment so a clear operational allergen control prerequisite program (PRP) needs to be in place and be effectively 


\section{ACCEPTED MANUSCRIPT}

implemented. After a PRP has been established then risk assessment linked to hazard characterization is "the tool that will determine where the real vulnerabilities are and where most effort should be focused" (Flanagan, nd: 3). Indeed the paper advocates the use of allergen mapping within a manufacturing unit in order to help identify the key physical areas where cross-contact can occur. FoodDrink Europe (2013) suggest that such a PRP should include:

- Product development guidelines in terms of allergens.

- Good hygiene, for example, rules regarding clothing, hand-washing and hand contact with foods.

- Cleaning of premises, equipment and tools.

- Handling of rework materials, for example, the conditions under which such products may be used.

- Waste management, for example, how waste should be labeled and kept separate from rework.

- Situations where potential cross-contact can occur between raw materials, products, production lines or equipment, and each employee's responsibility for preventing this.

- Production scheduling, and

- Labeling of raw materials, semi-finished goods and finished products.

Further the report identifies eight key mitigation elements to consider in the risk management approach used: people, suppliers, raw materials handling, equipment and factory design, manufacturing practices, consumer information, product development and change and documentation. In order to provide a more comprehensive approach to identifying and managing allergic reactions in sensitive individuals, identification of the wider range of foods that contain 


\section{ACCEPTED MANUSCRIPT}

these proteins of concern and the potential for cross-contact with extraneous plant material from such foods or food ingredients, is worthy of consideration so that effective PRP can be put in place and food businesses are able to operate within the emerging agenda of personalized medicine.

\section{QUANTIFYING ALLERGENIC RISK}

The conventional way for a food manufacturer to identify and list allergens during the product development phase would be according to food groups or ingredients (e.g. milk, wheat, peanuts) and with consideration of the regulatory requirements of the importing country. This consideration will still form the primary consideration in any allergen risk assessment process. Review of the proteins that foods contain would enable a more holistic and more comprehensive approach for risk assessment and management of allergens. There are multiple databases where technical personnel can access details on the proteins that each food contain that have the potential to cause an allergic reaction in sensitive individuals (Table 4).

The use of thresholds for allergens when determining the degree of risk has been established (Crevel et al. 2008). An FDA report (2006:2) identifies four approaches that could be used to determine allergen thresholds:

- Analytical methods based thresholds determined by the sensitivity of the analytical method(s) used to verify compliance. The report states that this approach is of limited value. FoodDrinkEurope (2013:22) suggest that "analytical testing is inappropriate for quality control purposes but supports upstream quality assurance, validating crosscontact control capability". 


\section{ACCEPTED MANUSCRIPT}

- Safety assessment based thresholds that calculate a "safe" level of allergen using the No Observed Adverse Effect Level (NOAEL) from human challenge studies and an appropriate uncertainty factor (UF) applied to account for knowledge gaps.

- Quantitative risk assessment based thresholds based on known or potential adverse health effects resulting from human exposure to a hazard; quantifying the levels of risk associated with specific exposures and the degree of uncertainty inherent in the risk estimate, and

- Statutorily derived thresholds using an exemption articulated in an applicable law and extrapolating from that to other potentially similar situations.

FDA (2006:3) concludes that of the four approaches, the quantitative risk assessment-based approach "provides the strongest, most transparent scientific analyses to establish thresholds for the major food allergens". However the report notes that a risk assessment approach could be used to set a single threshold level for proteins derived from any of the major food allergens to deliver statutory derived thresholds. FoodDrink Europe (2013:3) assert that although much work has been done to establish NOAEL and their use in food safety risk assessment, "agreement between stakeholders has not yet been reached on how to interpret this information in public health terms". In Australia and New Zealand, the Voluntary Incidental Trace Allergen Labeling (VITAL) system (see http://allergenbureau.net/vital/) is used to determine whether advisory labeling such as 'may-contain' statements) should be used on finished products (Flanagan, nd). The use of the VITAL system allows for the quantitative assessment of likely sources of allergen cross-contact from raw materials and the processing environment, and a review of the ability to reduce the allergenic material from all contributing sources (allergen.bureau.net, nd). Allergen 


\section{ACCEPTED MANUSCRIPT}

analysis is divided into different methods for different purposes. The most commonly used are lateral flow devices, enzyme linked immuno-sorbent assays (ELISA), mass spectrometry and polymerase chain reaction (PCR) assays (FoodDrink Europe, 2013). These methods are of value for verification purposes but do not support, mainly due to the cost of analysis, routine risk assessment activities that initiate quality planning with the aid of allergen databases. Therefore there are no cost effective on-line or real-time monitoring protocols available to identify the potential for an allergenic protein being present as a result of cross-contact on a batch by batch basis as the NOAEL and UF need to be defined for all proteins. Therefore the preventative approach that needs to be followed is one of quantitative risk based assessment. As a result of this study a comparison has been made between using a food group/ingredient and a protein based approach in terms of the degree of analysis that could be undertaken especially during the product development phase (Table 5).

Table 5 compares methods for identification of food allergens according to food/ingredient or protein groups, as well as the advantages and disadvantages of using each method, limitations and potential extensions of the process. It is important for food practitioners to consider whether the additive element of risk assessing for protein groups is appropriate in a given situation. To further illustrate the level of differentiation in terms of the depth of an allergen risk assessment firstly at the regulatory-derived food/ingredient group and then with an additive protein group based approach a product reformulation has been presented (Table 6). The example of a peanut and chocolate snack bar that is then supported by a peanut-free gluten-free product. With the current EU regulations for food group orientated product labeling the buckwheat and chia seeds would not have to be labeled as allergens on the packaging. 


\section{ACCEPTED MANUSCRIPT}

Allergenic reactions in susceptible individuals who have an allergenic pre-disposition to the plant protein could occur and cross-sensitivities to related proteins from a certain family can also take place e.g. the presence of profilin in dates and wheat and the presence of prolamin in buckwheat, raisins, and peanuts (Table 6). The nature of allergenic reaction to ingredients such as soy lecithin, sulfur dioxide, as well as wheat, peanuts and a functional hypersensitivity in some individuals to phenylethylamine and theobromine make this a very complex picture. The additional depth of a protein-based assessment is shown in Table 7. This shows the potential for reactivity to proteins in both the current and a revised product by sensitive individuals.

An example of the additive value of a protein-group based risk assessment is shown in Table 8 and how it can inform risk assessment activities either at the manufacturing level as in the example or at policy level.

\section{CONCLUDING REMARKS}

Protein components in food can trigger immune-mediated response in susceptible individuals. European law requires risk assessment to be undertaken by competent individuals to minimize food safety risk to consumers. Historically, allergen control legislation has been food focused with the requirement for on pack labeling, if specific food ingredients that are known allergens are present, and the need for formal food recalls in the event of misleading or inappropriate labeling. However this does not address the wider issue of the prolific nature of plant defense proteins that can trigger allergic reactions and even anaphylaxis. An additive protein-group based risk assessment approach that considers the plant-derived protein families involved in allergic response as well as the wider challenges that cause non immune-mediated response. This aim of this research was to identify a mechanism for decision makers when assessing the allergenic risk 


\section{ACCEPTED MANUSCRIPT}

to consumers associated with food products by focusing not only on prescribed food labeling, but also on the allergenic proteins of concern. This approach is of value for individuals who show cross-reactivity to plant proteins and could lead to more focused risk assessment activities and greater understanding of the role of proteins in causing an allergic response in the food industry. 


\section{ACCEPTED MANUSCRIPT}

\section{REFERENCES}

Afifi, M. A., Jiman-Fatani, A. A., El Saadany, S. and Fouad, M. A. (2015). Parasites-allergy paradox: Disease mediators or therapeutic modulators. Journal of Microscopy and Ultrastructure 3(2): 53-61.

AG (Australian Government) (nd) Australia New Zealand Food Standards Code - Standard 1.2.3

- Mandatory Warning and Advisory Statements and Declarations- F2011C00610

Available at: http://www.comlaw.gov.au/details/f2011c00610[Accessed on 20.08.15]

Ahlholm, J. U., Helander, M. L., Savolainen, J. (1998). Genetic and environmental factors

affecting the allergenicity of birch (Betula pubescens ssp. czerepanovii [Orl.] Hämet-Ahti)

pollen. Clinical and Experimental Allergy 28(11): 1384-1388.

Allergome (2015) Available at: http://www.allergome.org/index.php [Accessed on 20.08.15]

AllergenBureau.net (nd) Available at: http://allergenbureau.net/vital/ [Accessed on 20.10.15]

Armentia, A., Lombardero, M., Barber, D., Castrodeza, J., Calderon, S., Gil, F. J. M. and

Callejo, A. M. (2003). Occupational asthma in an agronomist caused by the lentil pest Bruchus lentis. Allergy, 58(11): 1200-1201.

Armentia, A., Lombardero, M., Blanco, C., Fernandez, S., Fernandez, A. and Sanchez-Monge, R. (2006). Allergic hypersensitivity to the lentil pest Bruchus lentis. Allergy, 61(9): 1112-1116. Bar-El Dadon, S., Pascual, C.Y., and Reifen, R. (2014), Food allergy and cross-reactivitychickpea as a test case, Food Chemistry, 165: 483-488

Bateman, A., Coin, L., Durbin, R., Finn, R. D., Hollich, V., Griffiths-Jones, S. et al. (2004). The Pfam protein families database. Nucleic Acids Research, 32: D138-141. 


\section{ACCEPTED MANUSCRIPT}

Bauditz, J., Norman, K., Biering, H., Lochs, H. and Pirlich, M. (2008). Severe weight loss caused by chewing gum. British Medical Journal, 336: 96-97.

Beggs, P. J. (2004). Impacts of climate change on aeroallergens: past and future. Clinical and Experimental Allergy, 34(1): 1507-1513.

Bell, R. G. (1996). IgE, allergies and helminth parasites: A new perspective on an old conundrum. Immunology and Cell Biology, 74: 337-345.

Born, P., Sekatcheva, M., Rösch, T. and Classen, M. (2006). Carbohydrate malabsorption in clinical routine: a prospective observational study. Hepatogastroenterology, 53(71): 673-677. Boyce, J. A., Assa'ad. A., Burks, A. W., Jones, S. M., Sampson, H. A., Wood, R. A. et al. (2010), Guidelines for the diagnosis and management of food allergy in the United States: Summary of the NIAID-sponsored expert panel report. Journal of Allergy and Clinical Immunology, 126(6): 1105-1118.

Breiteneder, H. and Mills, C. E. N. (2005). Plant food allergens - structural and functional aspects of allergenicity. Biotechnology Advances, 23(6): 395-399.

BRC (British Retail Consortium) (2015), BRC Global Standard Food Safety. Issue 7. BRC, London.

Breiteneder, H. and Radauer, C. (2004), A classification of plant food allergens. Journal of Allergy and Clinical Immunology, 113(5): 821-830.

BS EN ISO 22000:2005 (2005), Food Safety management systems - Requirements for any organization in the food chain BSI London. 


\section{ACCEPTED MANUSCRIPT}

Bush, R. K., Taylor, S. L., Holden, K., Nordlee, J. A., Busse, W. W. (1986). Prevalence of sensitivity to sulfiting agents in asthmatic patients. The American Journal of Medicine, 81(5): 816-820.

CBI Ministry of Foreign Affairs (2014), Chia product factsheet: Chia seeds in the EU and EFTA. Available from: https://www.cbi.eu/market-information/oilseeds/chia-seeds/ [Accessed 21.10.15] CAC (Codex Alimentarius Commission) (2003), Hazard Analysis and Critical Control Point (HACCP) System and Guidelines for its application, Codex Alimentarius Commission Food Hygiene Basic Texts (Revision 4). Available at: http://www.codexalimentarius.org CAC (Codex Alimentarius Commission) (1985), General Standard for the labelling of Prepackaged Foods (CODEX STAN 1-1985). Available at: http://www.codexalimentarius.org [Accessed on 21.10.15]

Carlsson, L., Nystrom, L.-E., Sundkvist, I., Markey, F. and Lindberg, U. (1977). Actin polymerizability is influenced by profilin, a low molecular weight protein in non-muscle cells. Journal of Molecular Biology, 115(3): 465-483.

Caubet, J.C. and Wang, J. (2011), Current understanding of egg allergy, Pediatric clinics of North America, 58(2): 427-443

CBRI (Campden BRI) (2009), HACCP: a practical guide (4 ${ }^{\text {th }}$ Edition) Guideline no.42 Editor R. Gaze ISBN 9780907503521

Cooper, P. J. (2004). Intestinal worms and human allergy. Parasite Immunology, 26: 455-467.

Crevel, R. W .R. Ballmer-Weber, B. K., Holzhauser, T., O'B. Hourihane, J., Knulst, A. C.

Mackie ,A Timmermans,. R., F. and Taylor, S. L. (2008). Thresholds for food allergens and their value to different stakeholders. Allergy, 63: 597-609. 


\section{ACCEPTED MANUSCRIPT}

Dagoye, D., Bekele, Z., Woldemichael, K., Nida, H., Yimam, M., Hall, A., Venn, A. J., Britton, J. R., Hubbard, R. and Lewis, S. A. (2003). Wheezing, allergy and parasite infection in children in urban and rural Ethiopia. American Journal of Respiratory and Critical Care Medicine, 167(10): 1369-1373.

Dean, T. (2000), Introduction. In, Dean, T. (ed.). Food Intolerance and the Food Industry. Cambridge: Woodhead Publishing Limited, pp.1-11.

Denery-Papini, S., Bodinier, M., Larre, C., Brossard, C., Pineau, F., Triballeau, S., Pietri, M., Battais, F., Mothes, T., Paty, E. and Moneret-Vautrin, D.-A. (2012), Allergy to deamidated gluten in patients tolerant to wheat: specific epitopes linked to deamidation. Allergy, 67(8): 1023-1032.

Denery-Papini, S., Bodinier, M., Pineau, F., Triballeau, S., Tranquet, O., Adel-Patient, K., Moneret-Vautrin, D. A., Bakan, B., Marion, D., Mothes, T., Mameri, H. and Kasarda, D. (2011), Immunoglobulin-E-binding epitopes of wheat allergens in patients with food allergy to wheat and in mice experimentally sensitized to wheat proteins. Clinical and Experimental Allergy, 41(10): 1478-1492.

Du Toit, G., Tsakok, T., Lack, S., and Lack, G. (2016), Prevention of food allergy, Journal of Allergy and Clinical Immunology, 137(4): 998-1010 EC (2013), Commission implementing decision of 22 January 2013 authorising an extension of use of Chia (Salvia hispanica) seed as a novel food ingredient under Regulation (EC) No 258/97 of the European Parliament and of the Council, Official Journal of the European Union L 21: 3435.

EC (2011) Regulation (EU) NO 1169/2011 of the European Parliament and of the Council 


\section{ACCEPTED MANUSCRIPT}

of 25 October 2011 on the provision of food information to consumers, amending Regulations (EC) No 1924/2006 and (EC) No 1925/2006 of the European Parliament and of the Council, and repealing Commission Directive 87/250/EEC, Council Directive 90/496/EEC, Commission Directive 1999/10/EC, Directive 2000/13/EC of the European Parliament and of the Council, Commission Directives 2002/67/EC and 2008/5/EC and Commission Regulation (EC) No 608/2004, Official Journal of the European Union, L 304: 18 - 63. EC (2007), Commission Directive 2007/68/EC of 27 November 2007 amending Annex IIIa to Directive 2000/13/EC of the European Parliament and of the Council as regards certain food ingredients, Official Journal of the European Union, L 310: 11 -14.

EC (2006), Directive 2006/142/EC of the European Parliament and of the Council of 22 December 2006 amending Annex IIIa of Directive 2000/13/EC of the European Parliament and of the Council listing ingredients which must under all circumstances appear on the labelling of foodstuffs, Official Journal of the European Union, L 368: 15 - 18.

EC (2003), Directive 2003/89/EC of the European Parliament and of the Council of 10 November 2003 amending Directive 2000/13/EC as regards indication of the ingredients present in foodstuffs, Official Journal of the European Union, L 308: 15 -18.

EFSA (2010), Scientific opinion on the substantiation of a health claim related to sugar-free chewing gum and reduction of tooth demineralisation which reduces the risk of dental caries pursuant to Article 14 of Regulation (EC) No 1924/2006. EFSA Journal, 8(10): 1-13.EFSA (2009), Scientific opinion on the safety of 'Chia seeds (Salvia hispanica L.) and ground whole Chia seeds' as a food ingredient. EFSA Journal, 996: 1-26. 


\section{ACCEPTED MANUSCRIPT}

EFSA (2009), Scientific opinion on the safety of 'Chia seeds (Salvia hispanica L.) and ground whole Chia seeds' as a food ingredient. EFSA Journal, 996: 1-26.

Egger M., Hauser, M., Mari, A., Ferreira, F. and Gadermaier, G. (2010), The role of lipid transfer proteins in allergic diseases. Current Allergy and Asthma Reports, 10: 326-335.

FARRP (Food Allergy Research and Resource Programme) (nd) Available at:

http://farrp.unl.edu

[Accessed on 20.08.15]

FDA (Food and Drug Administration) (2015), Approached to establish threshold for major food allergens and for gluten in food. Available at: http://www.fda.gov/Food/GuidanceRegulation/GuidanceDocumentsRegulatoryInformation/Aller gens/ucm106108.htm\#ii [Accessed 24.10.15]

FDA (Food and Drug Administration) (2013), Food Allergen Labeling and Consumer Protection Act (2004) Available at:

http://www.fda.gov/food/guidanceregulation/guidancedocumentsregulatoryinformation/allergens /ucm106187.htm_[Accessed on 20.08.15]

FDA (Food and Drug Administration) (2006), Approaches to Establish Thresholds for Major Food Allergens and for Gluten in Food, Available at:

http://www.fda.gov/downloads/Food/IngredientsPackagingLabeling/UCM192048.pdf [Accessed on 20.10.15]

Flanagan, S. (nd) White Paper: Quantitative Allergen Risk Assessment The Way Forward, RSSL. Available at: https://www.rssl.com/ /media/rssl/en/files/documents/whitepaper/quantitative-allergen-risk-assessment.pdf [Accessed on 20.10.15] 


\section{ACCEPTED MANUSCRIPT}

Flohr, C., Quinnell, R. J. and Britton, J. (2008). Do helminth parasites protect against atopy and allergic disease? Clinical and Experimental Allergy, 39(1): 20-32.

FoodDrinkEurope (2013), Guidance on food allergen management for food manufacturers. Available at: http://www.fooddrinkeurope.eu/uploads/press-

releases_documents/temp_file_FINAL_Allergen_A4_web1.pdf Accessedon 20.10.15]

Gendel, S. M. (2012), Comparison of international food allergen labelling regulations.

Regulatory Toxicology and Pharmacology, 63: 279-285.

Hamelmann, E. and Wahn, U. (2002), Immune responses to allergens early in life: when and why do allergies arise? Clinical \& Experimental Allergy 32(12): 1679-1681.

Hammer, H. F. and Hammer, J. (2012), Diarrhea caused by carbohydrate malabsorption. Gastroenterology Clinics of North America, 41(3): 611-627.

Hauser, M., Roulias, A., Ferreira, F. and Egger, M. (2010), Panallergens and their impact on the allergic patient. Allergy, Asthma \& Clinical Immunology, 6(1):1.

Hayes, D.F., Markus, H.S., Leslie, R.D., and Tool, E.J. (2014), Personalized medicine: risk prediction, targeted therapies and mobile health technology, BMC Medicine, 12:37

HC (nd) (Health Canada) Available at:

http://www.hc-sc.gc.ca/ahc-asc/media/nr-cp/_2012/2012-130fs-eng.php[Accessed on 20.08.15]

Hjelmroos, M., Schumacher, M. J., Van Hage-Hamsten, M. (1995). Heterogeneity of pollen proteins within individual Betula pendula trees. International Archives of Allergy and Immunology, 108(4): 368-376.

Hourihane, J. O’B. (2000), Symptoms of food intolerance. In, Dean, T. (ed.). Food Intolerance and the Food Industry. Cambridge: Woodhead Publishing Limited, pp.53-66. 


\section{ACCEPTED MANUSCRIPT}

Huertas, A. J., Lopez-Saez, M. P. and Carnes, J. (2011), Clinical profile of a Mediterranean population sensitised to palm pollen (Phoenix dactylifera). A retrospective study. Allergologia et Immunopathologia, 39(3): 145-149.

Jansen, S. C., van Dusseldorp, M., Bottema, K. C. and Dubois, A. E. J. (2003). Intolerance to dietary biogenic amines: a review. Annals of Allergy, Asthma and Immunology, 91(3): 233-241. Kanny, G., Gerbaux, V., Olszewski, A., Fremont, S., Empereur, F., Nabet, F. et al. (2001). No correlation between wine intolerance and histamine content of wine. Journal of Allergy and Clinical Immunology, 107(2): 375-378.

Khokhar, S., and Apenten, R.K.O. (2003), Anti-nutritional factors in food legumes and effects of processing. In: The role of food, agriculture, forestry and fisheries in human nutrition. (Eds:

Squires, Victor R), Encyclopedia of Life Support Systems (EOLSS), pp. 82-116. ISBN 1848266456

Kondo, N., Kuwabara, M., Kodama, H., Kumada, M., and Hori, N. (2015), Medical treatment of food allergies should be personalized, Personalized Medicine Universe, 4: 73-75

Kondo, N., Kuwabara, M., Matsui, E., Kodama, H., Kumada, M., Kondon, K., Nagata, T., Toisa, S., Mishima, H., Iwasaki, J., Matsuno, Y., Futura, Y., Shinoda, A., Yoshizaki, S., Tanaka, C., Akita, A., Taguchi, K., and Hirano, K., (2014) Personalised medicine for bronchial asthma and allergies, Personalized Medicine Universe, 3: 11-14

Kwaasi, $\quad$ A. A., Harfu, H. A., Parhar, R. S., Saleh, S., Collison, K. S., Panzani, R. C.M AlSedairy, S. T. and Al-Mohanna, F. A. (2002), Cross-reactivities between date palm (Phoeniz dactylifera L.) polypeptides and foods implicated in the oral allergy syndrome. Allergy, 57(6): $508-518$. 


\section{ACCEPTED MANUSCRIPT}

Lack, G. (2012), Update on risk factors for food allergy, Journal of Allergy and Clinical Immunology, 129(5): 1187-1197

Lanida-Pineda, C. M., Arroyo-Becerra, A., Rosas-Alvarado, A., Teran, L. M., Garcia-Cruz, M.

L., Marchat, L. A. and Reyes-Lopez. C. A. (2015), Major allergen from Amaranthus palmeri pollen is a profilin: Isolation, partial characterization and $\mathrm{IgE}$ recognition. Allergologia et Immunopathologia, 44(2): 160-166

Lehrer, S,B., Horner, W.E., Reese, G., and Taylor, S. (2009), Why are some proteins allergenic? Implications for biotechnology, Critical Reviews in Food Science and Nutrition, 36(6): 553-564 Levetin, E. (2001). Effects of climate change on airborne pollen. Journal of Allergy and Clinical Immunology, S107: s172.

Lomer, M. C. E., Parkes, G. C. and Sanderson, J. D. (2008). Review article: lactose intolerance in clinical practice - myths and realities. Alimentary Pharmacology and Therapeutics, 27(2): 93103.

López-Torrejón, G., Salcedo, G., Martí-Esteban, M., Díaz-Perales, A., Pascual, C. Y. and Sánchez-Monge, R. (2003), Len c 1, a major allergen and vicilin from lentil seeds: protein isolation and cDNA cloning. Journal of Allergy and Clinical Immunology, 112(6): 1208-1215. Lynch, N. R., Hagel, I., Perez, M., Di Prisco, M. V., Lopez, R. and Alvarez, N. (1993). Effect of antihelmintic treatment on the allergic reactivity of children in a tropical slum. Journal of Allergy and Clinical Immunology, 92(3): 404-411.

Maintz, L. and Novak, N. (2007). Histamine and histamine intolerance. American Journal of Clinical Nutrition, 85(5): 1185-1196. 


\section{ACCEPTED MANUSCRIPT}

Maleki, S.J., Viquez, O., Jacks, T., Dodo, H., Champagne, E.T., Chung, S.Y., and Landry, S.J., (2003) The major peanut allergen, Ara h 2, functions as a trypsin inhibitor and roasting enhances this function. Journal of Allergy and Clinical Immunology, 112(1): 190-5

Mameri, H., Denery-Papini, S., Pietri, M., Tranquet, O., Larre, C., Drouet, M., Paty, E., Jonathan, A.-M., Beaudouin, E., Moneret-Vautrin, D.-A., Moreau, T., Briozzo, P. and Gaudin, J.-C. (2012), Molecular and immunological characterization of wheat Serpin (Tri a 33).

Molecular Nutrition \& Food Research, 56(12): 1874-1883.

Manning, L. (2015). Categorizing food related illness: have we got it right? Critical Reviews in Food Science and Nutrition. DOI:10.1080/10408398.2015.1038776

Manso, L., Pastor, C., Perez-Gordo, M., Caes, B., Sastre, J. and Cuesta-Herranz, J. (2010), Cross-reactivity between coconut and lentil related to a $7 \mathrm{~S}$ globulin and an $11 \mathrm{~S}$ globulin. Allergy, 65(11): 1487-1488.

Matsuo, H., Yokooji, T. and Taogoshi, T. (2015), Common food allergens and their IgE-binding epitopes. Allergology International, 64(4): 332-343.

McMichael, A. J., Woodruff, R. E. and Hales, S. (2006). Climate change and human health: present and future risks. Lancet, 367(9513): 859-869.

Mills, E. N. C., Jenkins, J. A., Alcocer, M. J. and Shewry, P. R. (2004). Structural, biological, and evolutionary relationships of plant food allergens sensitizing via the gastrointestinal tract. Critical Reviews in Food Science and Nutrition, 44(5): 379-407.

Mills, E.N.C., Madsen, C., Shrewry, P.R., and Wichers, H.J., (2003), Food allergens of plant origin - their molecular and evolutionary relationships, Trends in Food Science and Technology, 14(4): $145-156$ 


\section{ACCEPTED MANUSCRIPT}

Mortimore, S. and Wallace, C. (2013), HACCP A Practical Approach. Third Edition. Springer. New York ISBN 9781461450276

Murzin, A. G., Brenner, S. E., Hubbard, T. and Chothia, C. (1995), SCOP: A structural classification of proteins database for the investigation of sequences and structures. Journal of Molecular Biology, 247: 536-540.

Nowak-Wegrzyn, A., Katz, Y., Mehr, S. S. and Koletzko, S. (2015), Non-IgE-mediated gastrointestinal food allergy. Journal of Allergy and Clinical Immunology 135(5): 1114-1124.

Palmer, L. J., Celedon, J. C., Weiss, S. T., Wang, B., Fang, Z. and Xu, X. (2002). Ascaris lumbridcoides infection is associated with increased risk of childhood asthma and atopy in rural China. American Journal of Respiratory and Critical Care Medicine, 165(11): 1489-1493.

Profet, M., (1991), The function of allergy: immunological defense against toxins, $Q$ Rev Biol, 66(1): 23-62.

Radauer, C. and Breiteneder, H. (2007). Evolutionary biology of plant food allergens. Journal of Allergy and Clinical Immunology 120(3): 518-525.

Radauer, C., Bublin, M., Wagner, S., Mari, A. and Breiteneder, H. (2008). Allergens are distributed into few protein families and possess a restricted number of biochemical functions. Journal of Allergy and Clinical Immunology, 121: 847-852.

Raithel, M., Weidenhiller, M., Hagel, A. F.-K., Hetterich, U., Neurath, M. F., Konturek, P. C. (2013). The malabsorption of commonly occurring mono and disaccharides. Deutsches Arzteblatt International, 110(46): 775-782. 


\section{ACCEPTED MANUSCRIPT}

Ramachandran, S., Christensen, H. E. M., Ishimaru, Y., Dong, C.-H., Wen, C.-M., Cleary, A. L. and Chua, N.-H. (2000), Profilin plays a role in cell elongation, cell shape maintenance and flowering in Arabidopsis. Plant Physiology, 124(4): 1637-1647.

Redekop, W.K. and Mladsi, D. (2013), The Faces of Personalized Medicine: A Framework for Understanding Its Meaning and Scope, Value in Health, 16(6): S4-S9

Sampson, H. A., Aceves, S., Bock, A., James, J., Jones, S. Lang, D. et al. (2014), Food allergy: A practice parameter update - 2014. Journal of Allergy and Clinical Immunology 134(5): 10161025

Shaw, I.C. (2013), Food Safety, The Science of Keeping Food Safe. Wiley Blackwell. Chichester UK. ISBN 9781444337228

Shewry, P. R., Napier, J. A. and Tatham, A. S. (1995), Seed storage proteins: structures and biosynthesis. Plant Cell, 7: 945-956.

Singer, B. D., Ziska, L. H., Frenz, D. A., Gebhard, D. E., Straka, J. G. (2005). Increasing Amb a 1 content in common ragweed (Ambrosia artemisiifolia) pollen as a function of rising atmospheric CO2 concentration. Functional Plant Biology, 32(7): 667-670.

Skypala, I. (2009), Fruits and vegetables. In, Skypala, I. and Venter, C. (Eds.). Food hypersensitivity. Chichester: Wiley Blackwell, pp. 147-166.

Skypala, I. (2011). Adverse food reactions - An emerging issue for adults. Journal of the American Dietetic Association, 111(12): 1877-1891.

Skypala, I. J., Williams, M., Reeves, L., Meyer, R. and Venter, C. (2015). Sensitivity to food additives, vaso-active amines and salicylates: a review of the evidence. Clinical and Translational Allergy, 5:34. 


\section{ACCEPTED MANUSCRIPT}

Smits, H. H., Hartgers, F. C. and Yazdanbakhsh, M. (2005). Helminth infections: Protection from atopic disorders. Current Allergy and Asthma Reports, 5(1): 42-50.

Stein, M., Greenberg, Z., Boaz, M., Handzel, Z. T., Meshesha, M. K. and Bentwich, Z. (2016).

The role of helminth infection and environment in the development of allergy: A prospective study of newly-arrived Ethiopian immigrants in Israel. PLoS Neglected Tropical Diseases, 10(1): e0004208.

Vally, H., de Klerk, N. and Thompson, P. J. (2000). Alcoholic drinks: Important triggers for asthma. Journal of Allergy and Clinical Immunology, 105(3): 462-467.

Van Ree, R. (2002), Clinical importance of non-specific lipid transfer proteins as food allergens. Biochemical Society Transaction 30: 910-913.

Van Ree, R. (1997), The oral allergy syndrome. In Amin S., Lahti, A. and Maibach, H. I. (eds.). Contact urticaria syndrome. London: CRC Press, pp. 289-299.

Van Winkle, R. C. and Chang, C. (2014), The biochemical basis and clinical evidence of food allergy due to lipid transfer proteins: A comprehensive review. Clinical Reviews in Allergy \& Immunology, 46(3): 211-224.

Venter, C. (2009), Classification and prevalence of food hypersensitivity. In, Skypala, I. and Venter, C. (Eds.). Food hypersensitivity. Chichester: Wiley Blackwell, pp. 3-21.

Vieths, S., Scheurer, S. and Ballmer-Weber, B. (2002), Current understanding of cross-reactivity of food allergens and pollen. Annals of the New York Academy of Sciences, 964(1): 47-68.

Viquez, O. M., Konan, K. N. and Dodo, H. W. (2003), Structure and organization of the genomic clone of a major peanut allergen gene, Ara h 1. Molecular Immunology, 40: 565-571. 


\section{ACCEPTED MANUSCRIPT}

Wallace, C.A., Sperber, W.H., and Mortimore, S.E., (2011), Managing HACCP and Food Safety Through the Global Supply Chain. Wiley Blackwell ISBN 9781405189118

Walsh, B.J., Barnett, D., Burley, R.W., Elliott, C., Hill, D.J., and Howden, M.E (1988), New allergens from hen's egg white and egg yolk. In vitro study of ovomucin, apovitellenin I and VI and phosvitin. Int Arch Allergy Appl Immunol, 87(1): 81-6

Wayne, P., Foster, S., Connolly, J., Bazzaz, F. and Epstein, P. (2002). Production of allergenic pollen by ragweed (Ambrosia artemisiifolia L.) is increased in $\mathrm{CO} 2$-enriched atmospheres. Annals of Allergy, Asthma and Immunology, 88(3): 279-282.

Wensing, M., Knulst, A., Piersma, S., O’Kane, F., Knol, E. F. and Koppelman, S. J. (2003).

Patients with anaphylaxis to pea can have peanut allergy caused by cross reactivity IgE to vicilin (Ara h 1). Journal of Allergy and Clinical Immunology, 111(2): 420-424.

WHO/IUIS (World Health Organisation/International Union of Immunological Societies) (2014), Allergen Nomenclature database. Available at: http://www.allergen.org/index.php [Accessed on 01.08.14]

Wilder-Smith, C. H., Materna, A., Wemerlinger, C. and Schuler, J. (2013). Fructose and lactose intolerance and malabsorption testing: the relationship with symptoms in functional gastrointestinal disorders. Alimentary Pharmacology and Therapeutics, 37(11): 1074-1083.

Ziska, L.H., Caulfield, F.A. (2000a). Rising $\mathrm{CO}_{2}$ and pollen production of common ragweed (Ambrosia artemisiifolia), a known allergy-inducing species: implications for public health. Australian Journal of Plant Physiology, 27(10): 893-898. 


\section{ACCEPTED MANUSCRIPT}

Ziska, L.H., Caulfield, F.A. (2000b). The potential influence of rising atmospheric carbon dioxide $(\mathrm{CO} 2)$ on public health: pollen production of common ragweed as a test case: World Resource Review, 2000(12): 449-457.

Ziska, L. H., Epstein, P. R. and Rogers, C. A. (2007). Climate change, aerobiology, and public health in the Northeast United States. Mitigation and Adaptation Strategies for Global Change, 13(5): 607-613.

Ziska, L.H., Epstein, P. R., Schlesinger, W. H. (2009). Rising $\mathrm{CO}_{2}$, climate change, and public health: Exploring the links to plant biology. Environmental Health Perspectives, 117(2): 155158.

Zopf, Y., Baenkler, H.W., Silbermann, A., Hahn, E.G., and Raithel, M. (2009), The differential diagnosis of food intolerance. Dtsch Arztebl Int, 106(21): 359-69. 


\section{ACCEPTED MANUSCRIPT}

Table 1. Regulatory requirements for allergen labeling by country (Sources: FDA 2013;

Gendel, 2012; EC 2011; AG nd; FARRP nd; HC nd)

\begin{tabular}{|c|c|c|c|c|c|c|c|c|c|c|}
\hline $\begin{array}{l}\text { Food } \\
\text { Type }\end{array}$ & $\mathbf{E U}$ & US & $\begin{array}{c}\text { Canad } \\
\text { a }\end{array}$ & $\begin{array}{l}\text { Australi } \\
\text { a/ New } \\
\text { Zealand }\end{array}$ & $\begin{array}{l}\text { Ho } \\
\text { ng } \\
\text { Ko } \\
\text { ng }\end{array}$ & $\begin{array}{l}\text { Chi } \\
\text { na }\end{array}$ & $\begin{array}{l}\text { Japa } \\
\mathbf{n} * *\end{array}$ & Korea & $\begin{array}{c}\text { Mexic } \\
\text { o, } \\
\text { Chile, } \\
\text { Argen } \\
\text { tina }\end{array}$ & $\begin{array}{l}\text { Venez } \\
\text { uela, } \\
\text { Nicara } \\
\text { gua, } \\
\text { Cuba, } \\
\text { Costa } \\
\text { Rica, } \\
\text { Colom } \\
\text { bia }\end{array}$ \\
\hline $\begin{array}{l}\text { Cereal } \\
\text { s with } \\
\text { gluten }\end{array}$ & $\begin{array}{l}\text { Cereals } \\
\text { containi } \\
\text { ng } \\
\text { gluten } \\
\text { (i.e. } \\
\text { wheat, } \\
\text { rye, } \\
\text { barley, } \\
\text { oats, } \\
\text { spelt, }\end{array}$ & Wheat & $\begin{array}{l}\text { Cereals } \\
\text { with } \\
\text { gluten } \\
\text { includi } \\
\text { ng } \\
\text { wheat }\end{array}$ & $\begin{array}{l}\text { Cereals } \\
\text { containi } \\
\text { ng } \\
\text { gluten } \\
\text { and their } \\
\text { products } \\
\text {, } \\
\text { namely, } \\
\text { wheat, } \\
\text { rye, }\end{array}$ & $X$ & & & & $\begin{array}{l}X \text { (not } \\
\text { wheat) }\end{array}$ & $X$ \\
\hline
\end{tabular}




\section{ACCEPTED MANUSCRIPT}

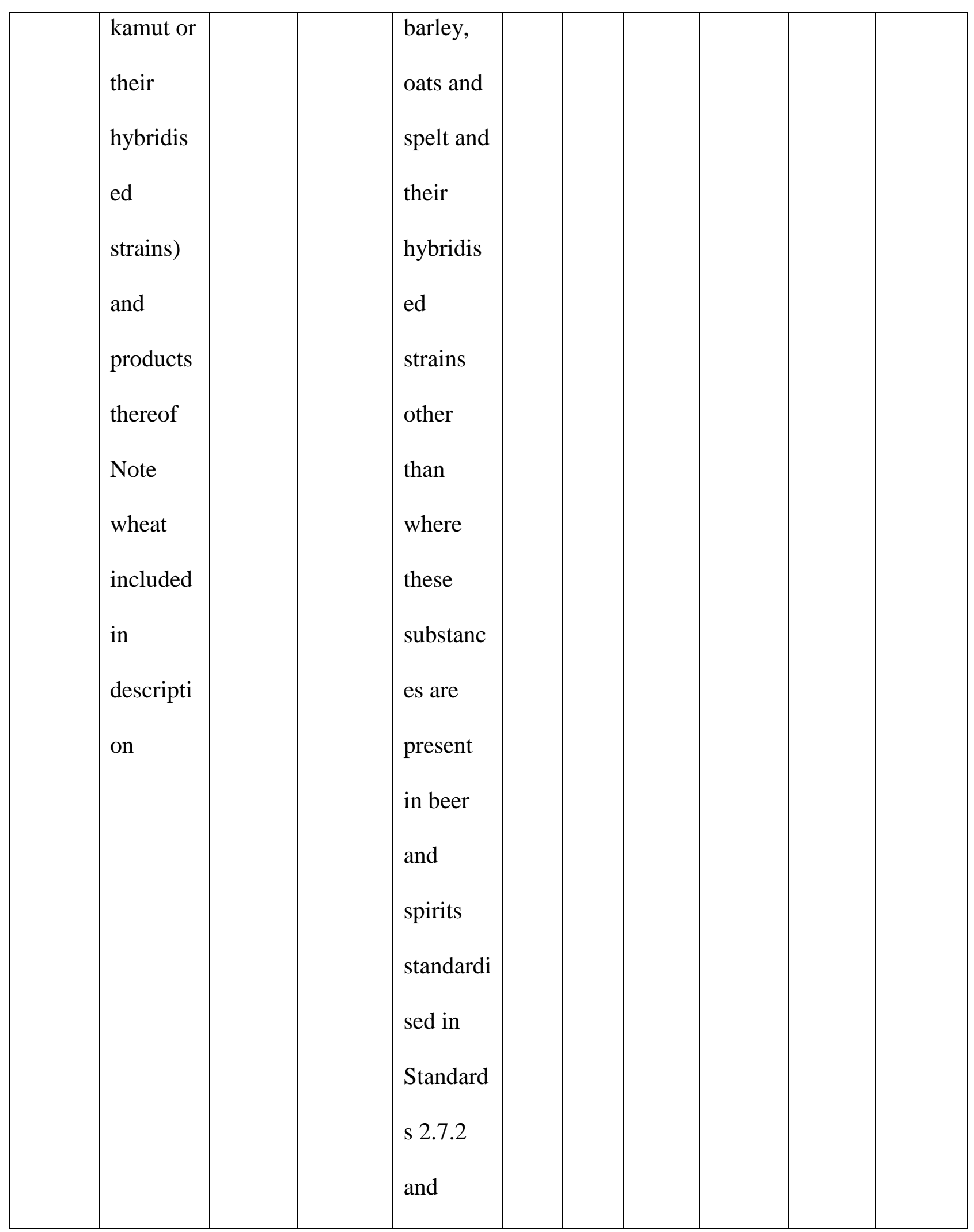




\section{ACCEPTED MANUSCRIPT}

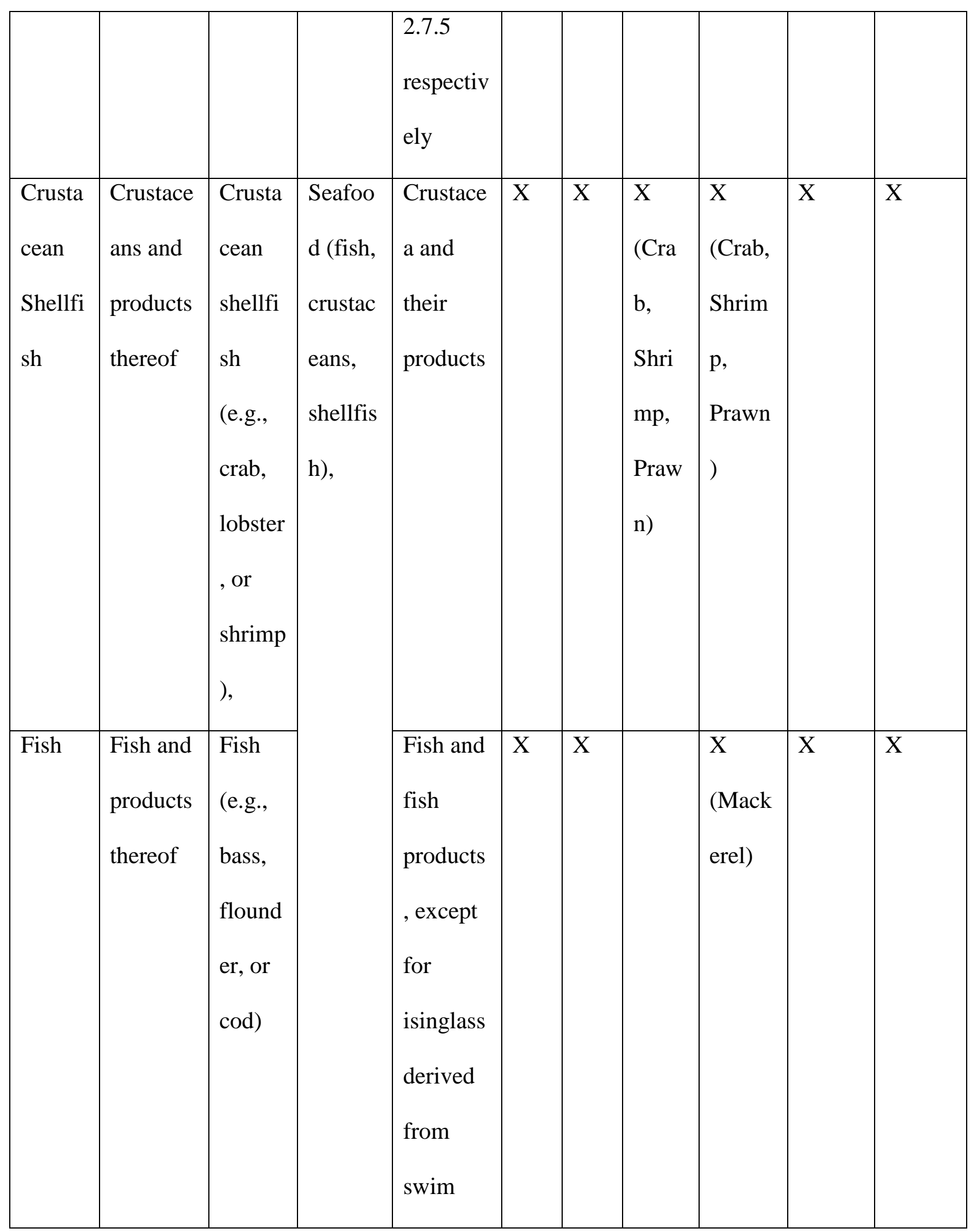




\section{ACCEPTED MANUSCRIPT}

\begin{tabular}{|c|c|c|c|c|c|c|c|c|c|c|}
\hline & & & & $\begin{array}{l}\text { bladders } \\
\text { and used } \\
\text { as a } \\
\text { clarifyin } \\
\text { g agent } \\
\text { in beer } \\
\text { and wine }\end{array}$ & & & & & & \\
\hline Egg & $\begin{array}{l}\text { Eggs } \\
\text { and } \\
\text { products } \\
\text { thereof }\end{array}$ & Egg & Eggs & $\begin{array}{l}\text { Egg and } \\
\text { egg } \\
\text { products }\end{array}$ & $X$ & $X$ & $X$ & $X$ & $X$ & $\mathrm{X}$ \\
\hline $\begin{array}{l}\text { Peanut } \\
\mathrm{s}\end{array}$ & $\begin{array}{l}\text { Peanuts } \\
\text { and } \\
\text { products } \\
\text { thereof }\end{array}$ & $\begin{array}{l}\text { Peanut } \\
\mathrm{S}\end{array}$ & $\begin{array}{l}\text { Peanut } \\
\mathrm{S}\end{array}$ & $\begin{array}{l}\text { Peanuts } \\
\text { and } \\
\text { peanut } \\
\text { products }\end{array}$ & $X$ & $X$ & $X$ & $X$ & $X$ & $\mathrm{X}$ \\
\hline $\begin{array}{l}\text { Soybe } \\
\text { ans }\end{array}$ & $\begin{array}{l}\text { Soybean } \\
\text { s and } \\
\text { products } \\
\text { thereof }\end{array}$ & $\begin{array}{l}\text { Soybe } \\
\text { ans }\end{array}$ & Soy & $\begin{array}{l}\text { Soybean } \\
\text { s and } \\
\text { soybean } \\
\text { products }\end{array}$ & $X$ & $X$ & & $X$ & X & $\mathrm{X}$ \\
\hline Milk & $\begin{array}{l}\text { Milk and } \\
\text { products } \\
\text { thereof }\end{array}$ & Milk & Milk & $\begin{array}{l}\text { Milk and } \\
\text { milk } \\
\text { products }\end{array}$ & $X$ & $\mathrm{X}$ & $\mathrm{X}$ & $X$ & $X$ & $\mathrm{X}$ \\
\hline
\end{tabular}




\section{ACCEPTED MANUSCRIPT}

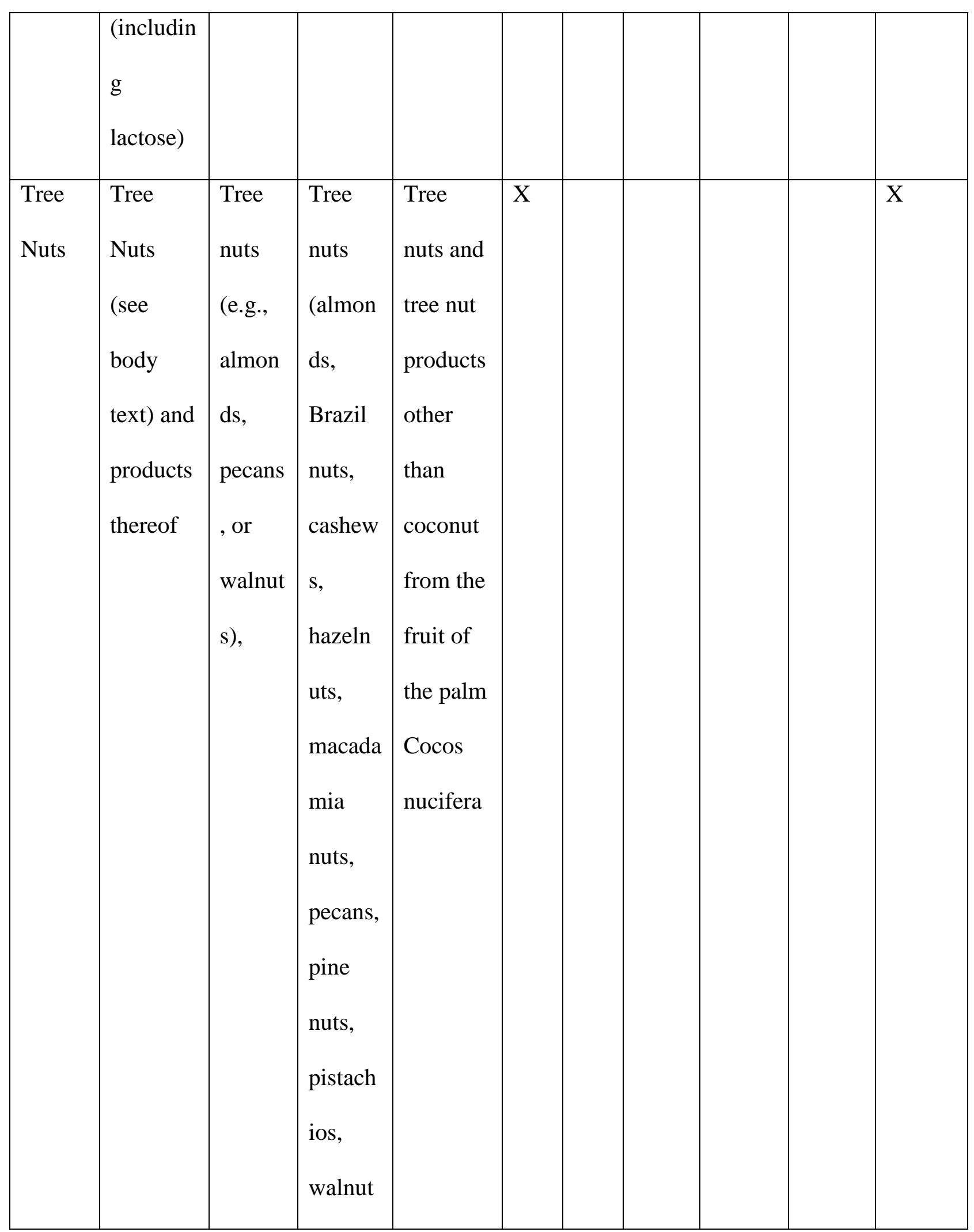




\begin{tabular}{|c|c|c|c|c|c|c|c|}
\hline & & & s) & & & & \\
\hline $\begin{array}{l}\text { Sulfite } \\
\mathrm{s}\end{array}$ & $\begin{array}{l}\text { Sulfur } \\
\text { dioxide } \\
\text { and } \\
\text { sulphites } \\
\text { at } \\
\text { concentr } \\
\text { ations } \\
\text { of } \geq 10 \\
\mathrm{mg} / \mathrm{kg} \text { or } \\
10 \\
\mathrm{mg} / \text { litre } \\
\text { expresse } \\
\mathrm{d} \text { as } \mathrm{SO}_{2}\end{array}$ & $\begin{array}{l}\geq 10 \\
\mathrm{mg} / \mathrm{kg} \\
*\end{array}$ & $\begin{array}{l}\text { Directl } \\
\mathrm{y} \\
\text { added } \\
\text { or } \geq 10 \\
\mathrm{mg} / \mathrm{kg}\end{array}$ & $\begin{array}{l}\text { Added } \\
\text { Sulfites } \\
\text { in } \\
\text { concentr } \\
\text { ations of } \\
10 \\
\mathrm{mg} / \mathrm{kg} \text { or } \\
\mathrm{more}\end{array}$ & $\begin{array}{l}\geq \\
10 \\
\mathrm{mg} / \\
\mathrm{kg}\end{array}$ & $\begin{array}{l}\geq 10 \\
\mathrm{mg} / \mathrm{kg}\end{array}$ & $\begin{array}{l}\geq 10 \\
\mathrm{mg} / \mathrm{kg}\end{array}$ \\
\hline $\begin{array}{l}\text { Musta } \\
\text { rd }\end{array}$ & $\begin{array}{l}\text { Mustard } \\
\text { and } \\
\text { products } \\
\text { thereof }\end{array}$ & - & $\begin{array}{l}\text { Mustar } \\
\text { d, }\end{array}$ & & & & \\
\hline $\begin{array}{l}\text { Sesam } \\
\text { e }\end{array}$ & $\begin{array}{l}\text { Sesame } \\
\text { seeds } \\
\text { and } \\
\text { products }\end{array}$ & - & $\begin{array}{l}\text { Sesame } \\
\text { seeds, }\end{array}$ & $\begin{array}{l}\text { Sesame } \\
\text { seeds } \\
\text { and } \\
\text { sesame }\end{array}$ & & & \\
\hline
\end{tabular}




\section{ACCEPTED MANUSCRIPT}

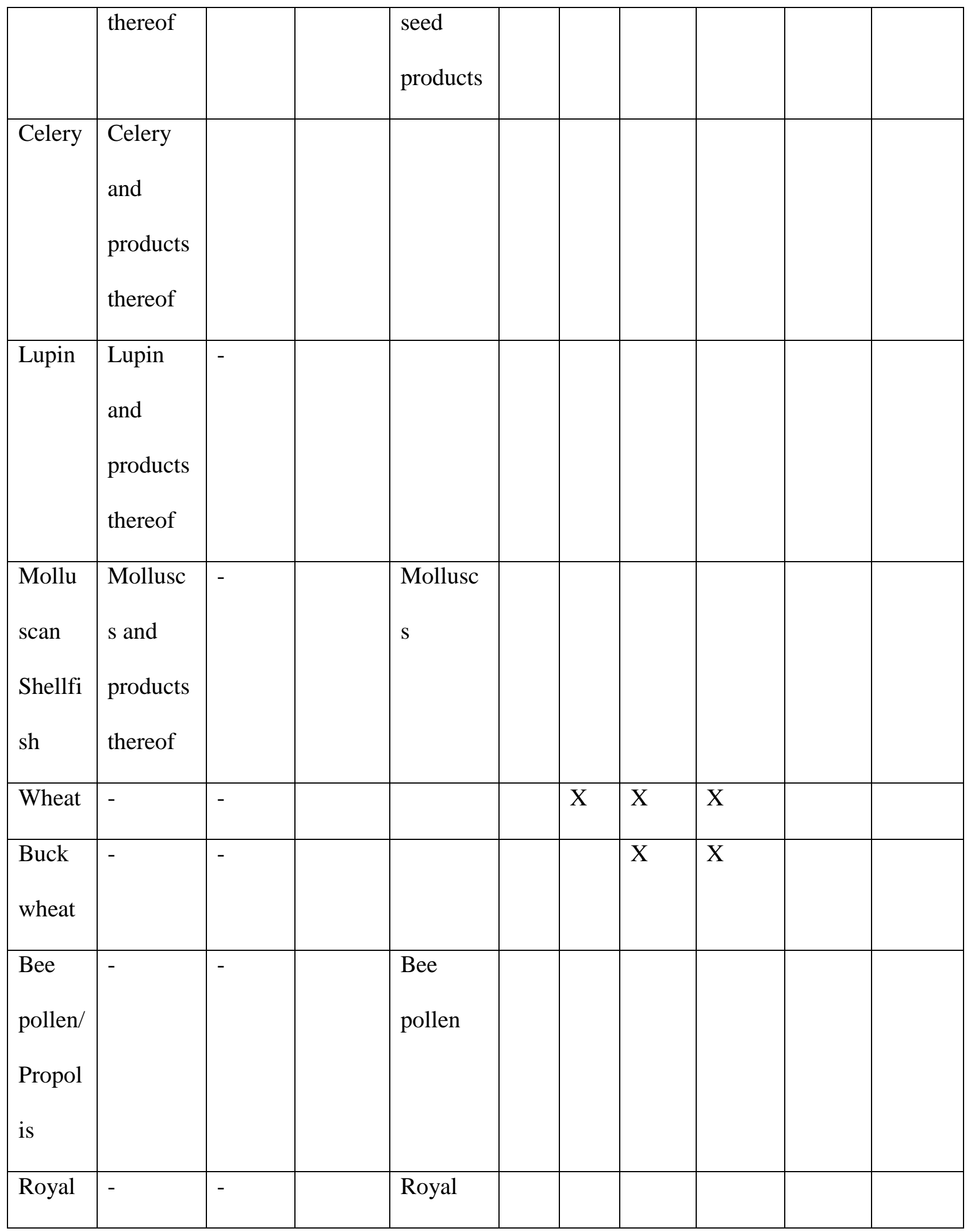




\section{ACCEPTED MANUSCRIPT}

\begin{tabular}{|l|l|l|l|l|l|l|l|l|l|l|}
\hline jelly & & & & jelly & & & & & & \\
\hline Peach & - & - & & & & & & $\mathrm{X}$ & & \\
\hline Pork & - & - & & & & & & $\mathrm{X}$ & & \\
\hline Tomat & - & - & & & & & & $\mathrm{X}$ & & \\
o & & & & & & & & & & \\
\hline
\end{tabular}

${ }^{*}$ Additional legislation

**voluntary labeling recommended for 20 other foods $\mathrm{X}$ indicates mandatory labeling is required. 


\section{ACCEPTED MANUSCRIPT}

Table 2. Common foods and associated protein allergens (Adapted from Walsh et al. 1988;

Maleki et al. 2003; Caubet and Wang, 2011; Denery-Papini et al. 2011, 2012; Mameri et al.

2012; Mortimore and Wallace 2013; Shaw 2013; WHO/IUIS, 2014; Matsuo et al. 2015,

Allergome, 2015)

\begin{tabular}{|c|c|c|}
\hline Food & $\begin{array}{c}\text { Animal or plant } \\
\text { species }\end{array}$ & Molecule (Allergen) \\
\hline $\begin{array}{l}\text { Bee pollen/ } \\
\text { Royal jelly }\end{array}$ & & Pollen proteins in honey or bee derived products \\
\hline Buckwheat & $\begin{array}{l}\text { Fagopyrum } \\
\text { esculentum } \\
\text { (Common } \\
\text { buckwheat) }\end{array}$ & $2 \mathrm{~S}$ albumin (Fag e 2); Vicilin-like protein (Fag e 3) \\
\hline Celery & Apium graveolens & $\begin{array}{l}\text { Pathogenesis-related protein, PR-10, Bet v } 1 \text { family member } \\
\text { (Api g 1); Non-specific lipid-transfer protein, type } 1 \\
\text { (nsLTP1) (Api g 2); Chlorophyll a-b binding protein, } \\
\text { chloroplast (Api g 3); Profilin (Api g 4); FAD-containing } \\
\text { oxidase (Api g 5); Non-specific lipid transfer protein type } 2 \\
\text { (Api g 6) }\end{array}$ \\
\hline \multirow[t]{2}{*}{$\begin{array}{l}\text { Crustacea } \\
\text { (examples) }\end{array}$} & $\begin{array}{l}\text { Charybdis feriatus } \\
\text { (crab) }\end{array}$ & Tropomyosin (Cha f 1) \\
\hline & $\begin{array}{l}\text { Metapenaeus ensis } \\
\text { (shrimp) }\end{array}$ & Tropomyosin (Met e 1); \\
\hline
\end{tabular}




\section{ACCEPTED MANUSCRIPT}

\begin{tabular}{|c|c|c|}
\hline & $\begin{array}{l}\text { Penaeus aztecus } \\
\text { (brown shrimp) }\end{array}$ & Tropomyosin (Pen a 1) \\
\hline & $\begin{array}{l}\text { Litopenaeus } \\
\text { vannamei (white } \\
\text { shrimp) }\end{array}$ & $\begin{array}{l}\text { Tropomyosin (Lit v 1); Arginine kinase (Lit v 2); Myosin } \\
\text { light chain } 2 \text { (Lit v 3); Sarcoplasmic calcium-binding protein } \\
\text { (Lit v 4) }\end{array}$ \\
\hline & $\begin{array}{l}\text { Pandalus borealis } \\
\text { (Northern shrimp) }\end{array}$ & Tropomyosin (Pan b 1) \\
\hline & $\begin{array}{l}\text { Penaeus indicus } \\
\text { (Indian white } \\
\text { shrimp) }\end{array}$ & Tropomyosin (Pen i 1) \\
\hline & $\begin{array}{l}\text { Penaeus monodon } \\
\text { (Black tiger shrimp) }\end{array}$ & $\begin{array}{l}\text { Tropomyosin (Pen m 1); Arginine kinase (Pen m 2); Myosin } \\
\text { light chain } 2 \text { (Pen m 3); Sarcoplasmic calcium-binding } \\
\text { protein (Pen m 4); Troponin C (Pen m 6) }\end{array}$ \\
\hline & $\begin{array}{l}\text { Crangon crangon } \\
\text { (North sea shrimp) }\end{array}$ & $\begin{array}{l}\text { Tropomyosin (Cra c 1); Arginine kinase (Cra c 2); } \\
\text { Sarcoplasmic calcium-binding protein (Cra c 4); Myosin } \\
\text { light chain } 1 \text { (Cra c 5); Troponin C (Cra c 6); } \\
\text { Triosephosphate isomerase (Cra c8) }\end{array}$ \\
\hline $\begin{array}{l}\text { Cereal } \\
\text { (excluding } \\
\text { wheat) }\end{array}$ & $\begin{array}{l}\text { Hordeum vulgare } \\
\text { (barley) }\end{array}$ & $\begin{array}{l}\text { Profilin (Hor v 12); } \alpha \text {-amylase inhibitor BMAI-1 precursor } \\
\text { (Hor v 15); } \alpha \text {-amylase (Hor v 16); } \beta \text {-amylase (Hor v 17); } \gamma \text { - } \\
\text { hordein } 3 \text { (Hor v 20) }\end{array}$ \\
\hline & Secale cereale (rye) & $\gamma$-secalin (Sec c 20); \\
\hline
\end{tabular}




\section{ACCEPTED MANUSCRIPT}

\begin{tabular}{|c|c|c|}
\hline Cow's milk & Bos domesticus & $\begin{array}{l}\alpha \text {-Lactalbumin (Bos d 4); } \beta \text {-Lactoglobulin (Bos d 5); Serum } \\
\text { albumin (Bos d 6); Immunoglobulin (Bos d 7); Caseins (Bos } \\
\text { d 8); } \alpha \text {-S1-casein (Bos d 9); } \alpha \text {-S2-casein (Bos d 10); } \beta \text {-casein } \\
\text { (Bos d 11); } \text {-casein (Bos d 12) }\end{array}$ \\
\hline Egg & Gallus domesticus & $\begin{array}{l}\text { Ovamucoid (Gal d 1); Ovalbumin (Gal d 2); Ovatransferrin } \\
\text { (Gal d 3); Lysosyme C (Gal d 4); serum albumin, } \alpha \text {-Livetin } \\
\text { (Gal d 5) - can also cause a cross reaction with poultry meat; } \\
\text { Phosvitin (Gal d 6); Apovitellenins I (Gal d Apo I); } \\
\text { Apovitellenins VI (Gal d Apo VI); fragment of vitellogenin } \\
\text { - } 1 \text { precursor (YGP42) }\end{array}$ \\
\hline \multirow[t]{3}{*}{$\begin{array}{l}\text { Fish } \\
\text { (examples) }\end{array}$} & $\begin{array}{l}\text { Gadus callarius } \\
\text { (Baltic cod) }\end{array}$ & $\beta$-parvalbumin ( $\mathrm{Gad}$ c 1$) ;$ \\
\hline & $\begin{array}{l}\text { Gadus morhua } \\
\text { (Atlantic cod) }\end{array}$ & $\begin{array}{l}\text { B-parvalbumin (Gad m 1); } \beta \text {-enolase (Gad } \mathrm{m} 2) \text {; Aldolase A } \\
(\operatorname{Gad} \mathrm{m} 3) \text {; }\end{array}$ \\
\hline & $\begin{array}{l}\text { Salmo salar } \\
\text { (Atlantic salmon) }\end{array}$ & $\begin{array}{l}\beta \text {-parvalbumin (Sal s 1); } \beta \text {-enolase (Sal s 2); Aldolase A (Sal } \\
\text { s 3) }\end{array}$ \\
\hline $\begin{array}{l}\text { Legumes } \\
\text { (examples) }\end{array}$ & $\begin{array}{l}\text { Glycine ussuruensis } \\
\text { (soy) } \\
\text { Lens culinaris } \\
\text { (lentil) }\end{array}$ & $\begin{array}{l}\text { Glycinin (Gly m 1); Defensin (Gly m 2); Profilin (Gly m 3); } \\
\text { Pathogenesis-related protein, PR-10, Bet v } 1 \text { family member } \\
\text { (Gly m 4); Vicilin ( (B-Conglycinin); (Gly m 5); Glycinin } \\
\text { (Gly m 6); Seed-specific biotinylated protein (Gly m 7); 2S } \\
\text { albumin (Gly m 8) } \\
\text { Gamma-vivilin subunit (Len c 1); Seed-specific biotinylated }\end{array}$ \\
\hline
\end{tabular}




\section{ACCEPTED MANUSCRIPT}

\begin{tabular}{|c|c|c|}
\hline & & $\begin{array}{l}\text { protein (Len c 2); Non-specific lipid transfer protein type } 1 \\
\text { (Len c 3) }\end{array}$ \\
\hline & $\begin{array}{l}\text { Lupinus } \\
\text { angustifolius } \\
\text { (lupin) }\end{array}$ & 7S seed storage globulin (vicilin-like) (Lup an 1) \\
\hline & $\begin{array}{l}\text { Cicer arietinum } \\
\text { (chickpea) }\end{array}$ & $\begin{array}{l}\text { 7S vicilin-like globulin (Cic a 1); heat shock protein } 70 \text { (Cic } \\
\text { a 10); } 2 \mathrm{~S} \text { albumin (Cic a } 2 \mathrm{~S} \text { albumin); lipid transfer protein } 1 \\
\text { (Cic a 3); Bet v 1-like protein (Cic a 4); 11S globulin (Cic a } \\
\text { 6); seed albumin (Cic a Albumin) }\end{array}$ \\
\hline & $\begin{array}{l}\text { Phaseolus vulgaris } \\
\text { (green bean) }\end{array}$ & Non-specific lipid transfer protein type 1 (Pha v 3 ) \\
\hline $\begin{array}{l}\text { Molluscs } \\
\text { (examples) }\end{array}$ & $\begin{array}{l}\text { Helix aspersa } \\
\text { (Brown garden } \\
\text { snail) }\end{array}$ & Tropomyosin (Hel as 1) \\
\hline & $\begin{array}{l}\text { Todarodes pacifus } \\
\text { (squid) }\end{array}$ & Tropomyosin (Tod p 1) Chitinase may be an allergen \\
\hline $\begin{array}{l}\text { Mustard } \\
\text { (examples) }\end{array}$ & $\begin{array}{l}\text { Sinapis alba } \\
\text { (yellow mustard) }\end{array}$ & $\begin{array}{l}\text { 2S albumin (Sin a 1); } 11 \mathrm{~S} \text { seed storage globulin (legumin- } \\
\text { like) (Sin a 2); Non-specific lipid-transfer protein, type } 1 \\
\text { (nsLTP1) (Sin a 3); Profilin (Sin a 4) }\end{array}$ \\
\hline Peach & $\begin{array}{l}\text { Prunus persica } \\
\text { (peach) }\end{array}$ & $\begin{array}{l}\text { Pathogenesis-related protein, PR-10 (Pru p 1); Thaumatin- } \\
\text { like protein (Pru p 2); nsLTP1 (Pru p 3); profiling (Pru p 4); } \\
\text { Gibberellin-regulated protein (Pru p 7) }\end{array}$ \\
\hline
\end{tabular}




\section{ACCEPTED MANUSCRIPT}

\begin{tabular}{|c|c|c|}
\hline Peanut & Arachis hypogaea & $\begin{array}{l}\text { Cupin Vicilin like (Ara h 1) causes severe reaction in those } \\
\text { with a peanut allergy including anaphylactic shock; } \\
\text { Conglutinin (Ara h 2) inhibits digestive enzyme trypsin; } \\
\text { Cupin Legumin-type (Ara h 3); (Ara h 4) renamed Ara h } \\
\text { 3.02; Profilin (Ara h 5); Conglutin (Ara h 6) and (Ara h 7); } \\
\text { Pathogenesis-related protein, PR-10, Bet v } 1 \text { family } \\
\text { member(Ara h 8); Non-specific lipid-transfer protein, type } 1 \\
\text { (nsLTP1) (Ara h 9); Oleosin (Ara h 10) and (Ara h } 11 \text { ); } \\
\text { Defensin (Ara h 12) and (Ara h 13), oleosin (Ara h } 14 \text { and } \\
\text { Ara h 15), non-specific Lipid Transfer Protein (Ara h } 16 \text { and } \\
\text { Ara h 17) }\end{array}$ \\
\hline Potato & Solanum tuberosum & $\begin{array}{l}\text { Patatin (Sola t 1); cathepsin D inhibitor PDI (Sola t 2); } \\
\text { cysteine protease inhibitor (Sola t 3); serine protease } \\
\text { inhibitor } 7 \text { (Sola t 4) }\end{array}$ \\
\hline $\begin{array}{l}\text { Pork/ } \\
\text { gelatine; }\end{array}$ & Sus domestica & $\begin{array}{l}\text { Sus d (kidney) related to allergy to galactose-alpha-1,3- } \\
\text { galactose allergy noted to albumin and } \gamma \text { globulin }\end{array}$ \\
\hline Rapeseed & Brassica napus & $2 \mathrm{~S}$ albumin $(\operatorname{Bra} \mathrm{n} 1)$ \\
\hline Sesame & $\begin{array}{l}\text { Sesamum indicum } \\
\text { (sesame) }\end{array}$ & $\begin{array}{l}\text { 2S albumin (Ses i } 1) \text { and (Ses i 2); 7S seed storage globulin } \\
\text { (vicilin-like) (Ses i 3); Oleosin (Ses i 4); (Ses i 5) }\end{array}$ \\
\hline Soybean & Glycine $\max$ & $\begin{array}{l}\text { Hydrophobic protein (Gly m 1); Profilin (Gly m 3); } \\
\text { Pathogenesis-related protein [PR-10, Bet v } 1 \text { (Gly m 4); } \beta \text { - } \\
\text { conglycinin (Gly m 5); Glycinin (Gly m 6); seed of }\end{array}$ \\
\hline
\end{tabular}




\section{ACCEPTED MANUSCRIPT}

\begin{tabular}{|c|c|c|}
\hline & & biotinylated protein (Gly m 7); 2S albumin (Gly m 8) \\
\hline $\begin{array}{l}\text { Sunflower } \\
\text { seed }\end{array}$ & Helianthus annuиs & 2S albumin (SFA 8) for seed \\
\hline Tomato & $\begin{array}{l}\text { Solanum } \\
\text { lycopersicum; } \\
\text { Lycopersicon } \\
\text { esculentum } \\
\text { (tomato) }\end{array}$ & $\begin{array}{l}\text { Profilin (Sola } 1 \text { 1); } \beta \text {-fructofuranosidase (Sola } 1 \text { 2); Non- } \\
\text { specific lipid transfer protein type } 2 \text { (Sola } 13 \text { ); Pathogenesis- } \\
\text { related protein, PR-10, Bet v } 1 \text { family member (Sola 14) }\end{array}$ \\
\hline \multirow[t]{5}{*}{$\begin{array}{l}\text { Tree nuts } \\
\text { (examples) }\end{array}$} & $\begin{array}{l}\text { Prunus dulcis } \\
\text { (almond) }\end{array}$ & $\begin{array}{l}\text { Non-specific lipid-transfer protein, type } 1 \text { (nsLTP1) (Pru du } \\
\text { 3); Profilin (Pru du 4): 60s acidic ribosomal prot. P2 (Pru du } \\
\text { 5); Amandin, 11S globulin legumin-like protein (Pru du 6) }\end{array}$ \\
\hline & $\begin{array}{l}\text { Anacardium } \\
\text { orientale (cashew) }\end{array}$ & Vicilin (Ana o 1); Legumin (Ana o 2); 2S albumin (Ana o 3) \\
\hline & $\begin{array}{l}\text { Bertholletia excels } \\
\text { (brazil nut) }\end{array}$ & $\begin{array}{l}2 \mathrm{~S} \text { sulfur-rich seed storage albumin (Ber e 1); } 11 \mathrm{~S} \text { seed } \\
\text { storage globulin (legumin-like) (Ber e 2) }\end{array}$ \\
\hline & $\begin{array}{l}\text { Carya illinoiesis } \\
\text { (pecan) }\end{array}$ & $\begin{array}{l}\text { 2S seed storage albumin (Car i 1); Legumin seed storage } \\
\text { protein (Car i 4) }\end{array}$ \\
\hline & $\begin{array}{l}\text { Corylus avellana } \\
\text { (hazelnut) }\end{array}$ & $\begin{array}{l}\text { Pathogenesis-related protein, PR-10, Bet v } 1 \text { family member } \\
\text { (Cor a 1); Profilin (Cor a 2); Non-specific lipid-transfer } \\
\text { protein, type } 1 \text { (nsLTP1) (Cor a 8); } 11 \mathrm{~S} \text { seed storage } \\
\text { globulin (legumin-like) (Cor a 9); 7S seed storage globulin } \\
\text { (vicilin-like) (Cor a 11); Oleosin (Cor a 12) and (Cor a 13); }\end{array}$ \\
\hline
\end{tabular}




\section{ACCEPTED MANUSCRIPT}

\begin{tabular}{|c|c|c|}
\hline & & $2 \mathrm{~S}$ albumin (Cor a 14$)$ \\
\hline & $\begin{array}{l}\text { Juglans regia } \\
\text { (English walnut) }\end{array}$ & $\begin{array}{l}\text { 2S seed storage albumin (Jug r 1); } 7 \mathrm{~S} \text { seed storage globulin } \\
\text { (vicilin-like) (Jug } \mathrm{r} 2 \text { ); Non-specific lipid-transfer protein, } \\
\text { type } 1 \text { (nsLTP1) (Jug r } 3) ; 11 \mathrm{~S} \text { seed storage globulin } \\
\text { (legumin-like) (Jug r 4); }\end{array}$ \\
\hline & $\begin{array}{l}\text { Juglans nigra } \\
\text { (Black walnut) }\end{array}$ & $\begin{array}{l}\text { 2S seed storage albumin (Jug n 1); 7S seed storage globulin } \\
\text { (vicilin-like) (Jug n 2); }\end{array}$ \\
\hline & $\begin{array}{l}\text { Pistacia vera } \\
\text { (pistachio nut) }\end{array}$ & $\begin{array}{l}\text { 2S albumin (Pis v 1); } 11 \mathrm{~S} \text { globulin subunit (Pis v 2) and (Pis } \\
\text { v 5); Vicilin-like protein (Pis v 3); Manganese superoxide } \\
\text { dismutase (Pis v 4); }\end{array}$ \\
\hline Wheat & $\begin{array}{l}\text { Triticum aestivum } \\
\text { (wheat) }\end{array}$ & 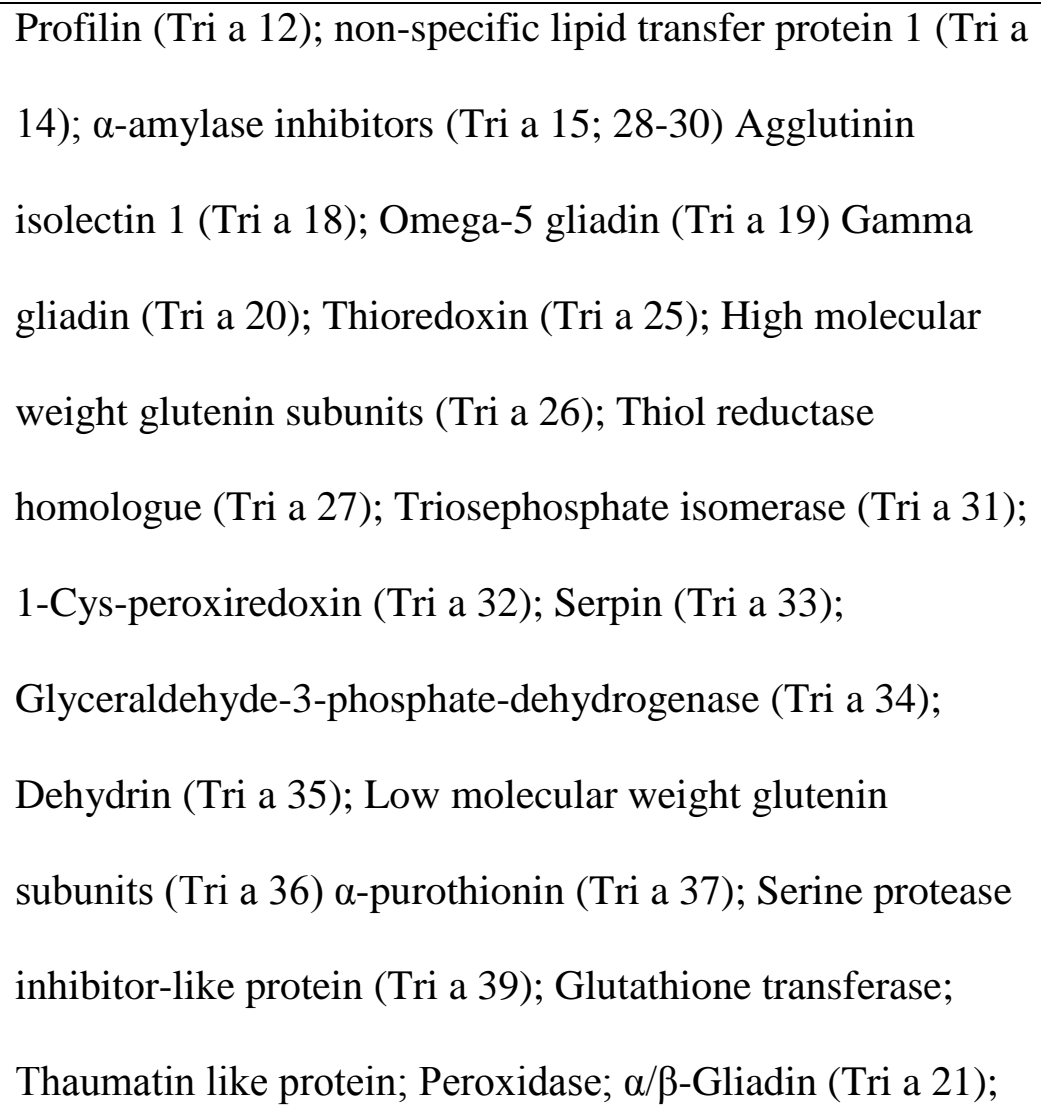 \\
\hline
\end{tabular}




\section{ACCEPTED MANUSCRIPT}

\begin{tabular}{|l|l|l|}
\hline & & $\gamma$-Gliadin (Tri a 20); $\omega 1,2$-Gliadin; $\omega 5$-Gliadin (Tri a 19) \\
\hline
\end{tabular}

This table is not designed to be an exhaustive list, but to give an indication of the complexity of allergenic protein classification and the distribution of protein superfamilies between different foods. 


\section{ACCEPTED MANUSCRIPT}

Table 3. Examples of cross reactivity between pollens with fruits and vegetables (Skypala, 2009; Vieths et al. 2002)

\begin{tabular}{|l|l|}
\hline $\begin{array}{l}\text { If an individual is } \\
\text { allergic to: }\end{array}$ & He / she may have a reaction to: \\
\hline Birch / mugwort & Celery, carrot, spices, sunflower seed, honey \\
\hline Birch pollen & $\begin{array}{l}\text { Apples, apricot, peaches, plums, nectarines, cherries, carrots, celery, } \\
\text { potatoes, hazelnuts, pears, almonds, peanuts, other nuts }\end{array}$ \\
\hline Ragweed pollen & Watermelon and other melon, banana, courgette, cucumber \\
\hline Grass & $\begin{array}{l}\text { Melon, watermelon, orange, tomato, potato, peanut, Swiss chard } \\
\text { Hazelnut, peach, apple, melon, kiwi, peanuts, maize, chickpea, lettuce, }\end{array}$ \\
\hline Plane & $\begin{array}{l}\text { Avocado, chestnut, banana, passion fruit, kiwi fruit, papaya, mango, } \\
\text { tomato, pepper, potato, celery }\end{array}$ \\
\hline Latex & \\
&
\end{tabular}




\section{ACCEPTED MANUSCRIPT}

Table 4. Reference Databases for food allergens

\begin{tabular}{|c|c|c|c|}
\hline Title & Country & Web address & Institution \\
\hline $\begin{array}{l}\text { AllergenOnline } \\
\text { (FARRP) }\end{array}$ & US & http://www.allergenonline.org/ & $\begin{array}{l}\text { University of Nebraska- } \\
\text { Lincoln }\end{array}$ \\
\hline $\begin{array}{l}\text { Allergome } \\
\text { Database }\end{array}$ & Italy & http://www.allergome.org & $\begin{array}{l}\text { Consortia including } \\
\text { University of } \\
\text { Queensland }\end{array}$ \\
\hline $\begin{array}{l}\text { ALLFam } \\
\text { (Radauer et al. } \\
\text { 2008) }\end{array}$ & Austria & http://www.meduniwien.ac.at/allfam & $\begin{array}{l}\text { Medizinische Universitat } \\
\text { Wien. Database } \\
\text { combines data from } \\
\text { Allergome and PFam } \\
\text { (http://pfam.xfam.org) }\end{array}$ \\
\hline Informall & UK & $\begin{array}{l}\text { http://www.inflammation- } \\
\text { repair.manchester.ac.uk/informAll/ }\end{array}$ & University of Manchester \\
\hline $\begin{array}{l}\text { Pfam } 29.0 \\
\text { (Bateman et al. } \\
\text { 2004) }\end{array}$ & UK & http://pfam.xfam.org/ & $\begin{array}{l}\text { Wellcome Trust Sanger } \\
\text { Institute, UK; European } \\
\text { Bioinformatics Institute } \\
\text { (EMBL-EBI), UK }\end{array}$ \\
\hline $\begin{array}{l}\text { Structural } \\
\text { Database of } \\
\text { Allergenic }\end{array}$ & US & http://fermi.utmb.edu/ & $\begin{array}{l}\text { University of Texas } \\
\text { Medical Branch }\end{array}$ \\
\hline
\end{tabular}




\section{ACCEPTED MANUSCRIPT}

\begin{tabular}{|l|l|l|l|}
\hline Proteins & & & \\
(SDAP) & & & \\
\hline WHO/IUIS & International & http://www.allergen.org/ & The World Health \\
Nomenclature & & & Organization and \\
Database & & & International Union of \\
\hline
\end{tabular}




\section{ACCEPTED MANUSCRIPT}

Table 5. Comparison of the mechanism for identification of allergens according to

food/ingredient or protein group

\begin{tabular}{|c|c|c|}
\hline Items & Food/ingredient group & Protein group \\
\hline \multirow[t]{3}{*}{$\begin{array}{l}\text { Mechanisms } \\
\text { for } \\
\text { identification }\end{array}$} & $\begin{array}{l}\text { List food formulation or } \\
\text { ingredients present in food by } \\
\text { name }\end{array}$ & $\begin{array}{l}\text { List food formulation or food } \\
\text { ingredients present. }\end{array}$ \\
\hline & $\begin{array}{l}\text { Identify allergenic foods and } \\
\text { the requirement for labelling } \\
\text { based on food groups and } \\
\text { according to the legislation in } \\
\text { importing countries (see } \\
\text { Table 1) }\end{array}$ & $\begin{array}{l}\text { Identify allergens based on food } \\
\text { and food ingredients as a } \\
\text { headline. }\end{array}$ \\
\hline & $\begin{array}{l}\text { Use of allergen risk } \\
\text { assessment tools that have } \\
\text { determined quantitative } \\
\text { thresholds at which an } \\
\text { allergic reaction is likely to } \\
\text { occur }\end{array}$ & $\begin{array}{l}\text { Identify and cross check protein } \\
\text { superfamily among list of } \\
\text { allergens with the help of } \\
\text { databases (e.g. WHO/IUIS, } \\
\text { Allergome, AllFam, } \\
\text { AllergenOnline see Table 4). }\end{array}$ \\
\hline Advantages & $\begin{array}{l}\text { Allows prompt identification } \\
\text { as industries will list foods } \\
\text { determined in legislation as } \\
\text { allergens according to food }\end{array}$ & $\begin{array}{l}\text { Allows cross examination for } \\
\text { potential new food allergens or } \\
\text { cross reactivity with other foods } \\
\text { and pollens. }\end{array}$ \\
\hline
\end{tabular}




\section{ACCEPTED MANUSCRIPT}

\begin{tabular}{|c|c|c|}
\hline & $\begin{array}{l}\text { group. Easy communication } \\
\text { to consumers compared to a } \\
\text { protein approach. }\end{array}$ & $\begin{array}{l}\text { Assists in preliminary risk } \\
\text { assessment of novel food } \\
\text { ingredients used for new product } \\
\text { formulation. } \\
\text { Enables businesses to be ready } \\
\text { for the concept of personalized } \\
\text { medicine or personalized } \\
\text { healthcare. } \\
\text { Enables provision of information } \\
\text { for customers via social media } \\
\text { and online networks. }\end{array}$ \\
\hline Limitations & $\begin{array}{l}\text { Less comprehensive } \\
\text { approach } \\
\text { Potential for food ingredients } \\
\text { to result in cross reactions } \\
\text { and cause sensitivity when } \\
\text { individuals may not have } \\
\text { awareness of presence. }\end{array}$ & $\begin{array}{l}\text { Protein family-based risk } \\
\text { assessment adds another layer of } \\
\text { complexity hence requires } \\
\text { expertise / knowledge in } \\
\text { allergenic proteins and division } \\
\text { of protein superfamilies and } \\
\text { families and impact of food } \\
\text { processing e.g. heat treatment. } \\
\text { May cause 'search fatigue' to } \\
\text { cross examine protein allergens. }\end{array}$ \\
\hline Extensions & \multicolumn{2}{|c|}{ Databases (Table 4 provide quick referencing for cross reactions } \\
\hline
\end{tabular}




\section{ACCEPTED MANUSCRIPT}

\begin{tabular}{|l|l|}
\hline & between different plant food proteins and non-related food proteins) \\
\hline
\end{tabular}




\section{ACCEPTED MANUSCRIPT}

Table 6. Case study example using an approach of identification of allergens according to

food groups

\begin{tabular}{|c|c|c|c|}
\hline \multicolumn{2}{|c|}{ Current snack bar } & \multicolumn{2}{|c|}{$\begin{array}{l}\text { Alternative snack bar reformulated to remove } \\
\text { wheat flour and chopped peanuts }\end{array}$} \\
\hline $\begin{array}{l}\text { Peanuts and } \\
\text { raisin choco- } \\
\text { top bar }\end{array}$ & $\begin{array}{l}\text { Allergens identified } \\
\text { according to food } \\
\text { groups or } \\
\text { preservatives }\end{array}$ & $\begin{array}{l}\text { Chia seed and dates } \\
\text { choco-top bar (gluten } \\
\text { free) }\end{array}$ & $\begin{array}{c}\text { Allergens identified } \\
\text { according to food groups } \\
\text { or preservatives }\end{array}$ \\
\hline Water & None & Water & None \\
\hline Xylitol & $\begin{array}{l}\text { Risk of diarrhoea at } \\
\text { excessive intake of } \\
\text { polyols (EFSA, 2010) }\end{array}$ & Xylitol & $\begin{array}{l}\text { Risk of diarrhoea at } \\
\text { excessive intake of polyols } \\
(\text { EFSA, 2010) }\end{array}$ \\
\hline $\begin{array}{l}\text { Chopped } \\
\text { peanuts }\end{array}$ & Peanuts & $\begin{array}{l}\text { Chia seeds (Novel } \\
\text { food) } \\
\text { (recognised as novel } \\
\text { ingredient and could be } \\
\text { sold and consumed in } \\
\text { EU but usage is still } \\
\text { restricted to bakery, } \\
\text { cereals and seed mixes } \\
\text { (EC, 2013) }\end{array}$ & $\begin{array}{l}\text { There are still } \\
\text { uncertainties with regard } \\
\text { to potential allergenicity } \\
\text { of Chia seeds, however } \\
\text { there are potential cross } \\
\text { reactivity with peanut and } \\
\text { sesame (EFSA, 2009) }\end{array}$ \\
\hline Wheat flour & Wheat (gluten) & Buckwheat flour & Known allergenic \\
\hline
\end{tabular}




\section{ACCEPTED MANUSCRIPT}

\begin{tabular}{|l|l|l|l|}
\hline & & & reactions in Japan and \\
Korea
\end{tabular}




\section{ACCEPTED MANUSCRIPT}

Table 7. Case study example of additional protein focused risk assessment approach for both current and new snack bars

\begin{tabular}{|c|c|c|c|c|}
\hline \multicolumn{2}{|c|}{$\begin{array}{l}\text { Current confectionary bar } \\
\text { produced by case study example }\end{array}$} & \multicolumn{3}{|c|}{$\begin{array}{l}\text { New confectionary bar to be produced by case study } \\
\text { example }\end{array}$} \\
\hline \multicolumn{2}{|c|}{ Peanuts and raisin choco-top bar } & \multicolumn{3}{|c|}{ Chia seeds and dates choco top bar (gluten free) } \\
\hline $\begin{array}{c}\text { Ingredients } \\
\text { with examples } \\
\text { of common } \\
\text { allergens }\end{array}$ & $\begin{array}{l}\text { Allergenic } \\
\text { protein groups }\end{array}$ & $\begin{array}{l}\text { Ingredients with } \\
\text { examples of } \\
\text { rare and novel } \\
\text { ingredients }\end{array}$ & $\begin{array}{l}\text { Allergenic } \\
\text { protein groups }\end{array}$ & $\begin{array}{c}\text { Potential } \\
\text { allergen } \\
\text { identification by } \\
\text { food industries }\end{array}$ \\
\hline $\begin{array}{l}\text { Chopped } \\
\text { peanuts } \\
\text { (Arachis } \\
\text { hypogaea) }\end{array}$ & $\begin{array}{l}\text { Contains cupin } \\
\text { (e.g. Ara h 1, Ara } \\
\text { h 3); prolamin } \\
\text { (Ara h 2, 16, 17); } \\
\text { pathogenesis- } \\
\text { related proteins } \\
\text { (Ara h } 8,9 \text { ) }\end{array}$ & $\begin{array}{l}\text { Chia seeds } \\
\text { (Salvia } \\
\text { hispanica) } \\
\text { (not one of the } \\
\text { foods requiring } \\
\text { allergen labeling } \\
\text { in EU) }\end{array}$ & $\begin{array}{l}\text { Non-identified on } \\
\text { allergen.org }\end{array}$ & $\begin{array}{l}\text { There are still } \\
\text { uncertainties } \\
\text { with regard to } \\
\text { potential } \\
\text { allergenicity of } \\
\text { Chia seeds, } \\
\text { however there } \\
\text { are potential } \\
\text { cross reactivities } \\
\text { for those with } \\
\text { peanut and } \\
\text { sesame allergies } \\
\text { (EFSA, 2009) }\end{array}$ \\
\hline
\end{tabular}




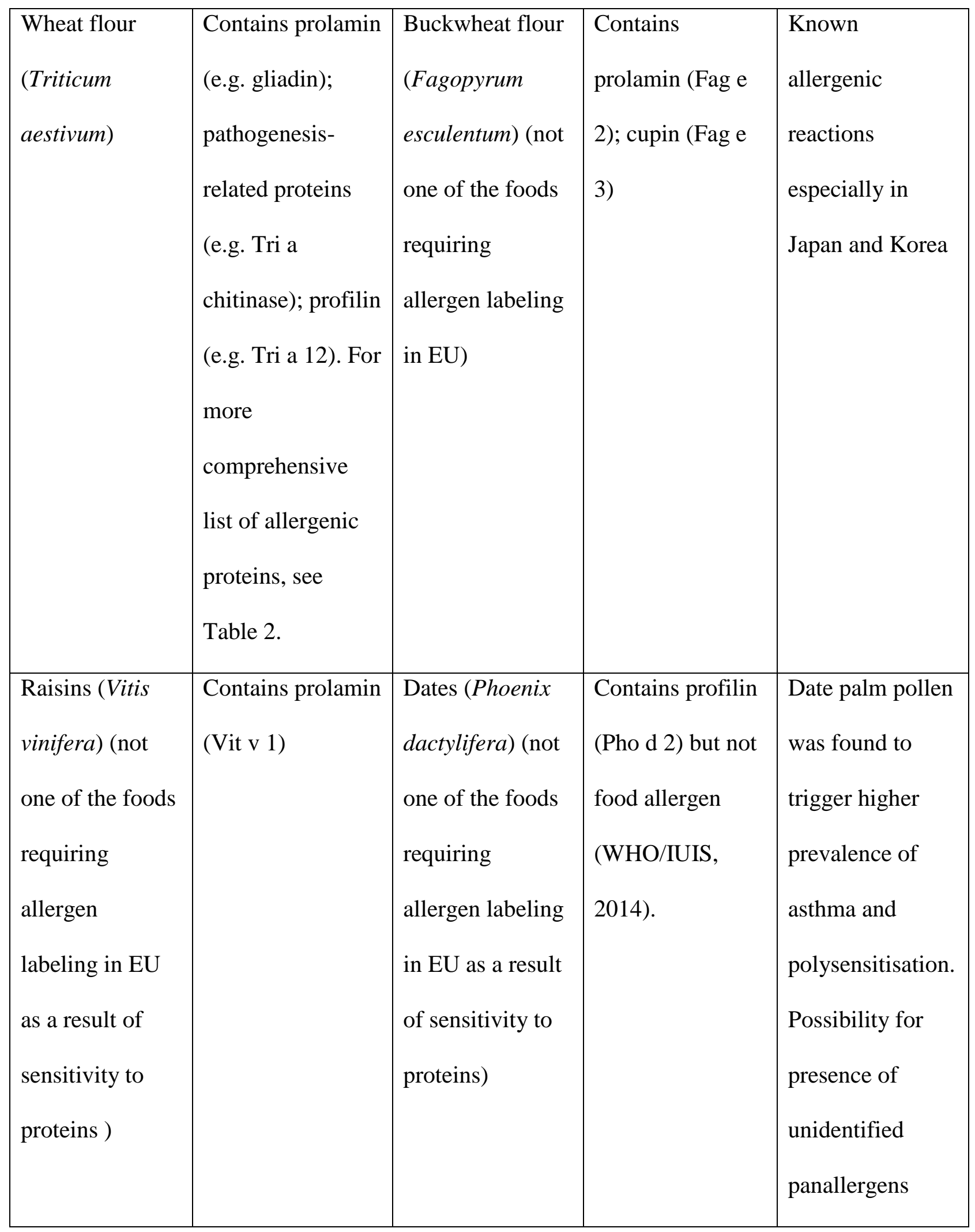




\section{ACCEPTED MANUSCRIPT}

\begin{tabular}{|c|c|c|c|c|}
\hline & & & & $\begin{array}{l}\text { (Huertas et al., } \\
2011) \text {. } \\
\text { May cross react } \\
\text { with pollens such } \\
\text { as Bermuda grass } \\
\text { (Cynodon } \\
\text { dactylon), } \\
\text { cultivated rye } \\
\text { (Secale cereale), } \\
\text { Timothy grass } \\
\text { (Phleum } \\
\text { pratense); } \\
\text { Sydney golden } \\
\text { wattle (Acacia } \\
\text { longifolia) } \\
\text { (Kwaasi et al. }\end{array}$ \\
\hline $\begin{array}{l}\text { Chocolate } \\
\text { topping }\end{array}$ & $\begin{array}{l}\text { Contains } \\
\text { phenylethylamine } \\
\text { and theobromine } \\
\text { (may result in } \\
\text { food }\end{array}$ & $\begin{array}{l}\text { Chocolate } \\
\text { topping }\end{array}$ & $\begin{array}{l}\text { Contains } \\
\text { phenylethylamine } \\
\text { and theobromine } \\
\text { (may result in } \\
\text { food }\end{array}$ & \\
\hline
\end{tabular}




\section{ACCEPTED MANUSCRIPT}

\begin{tabular}{|l|l|l|l|l|}
\hline & $\begin{array}{l}\text { hypersensitivity }- \\
\text { e.g. headache) }\end{array}$ & & hypersensitivity - & \\
& & e.g. headache) & \\
\hline
\end{tabular}




\section{ACCEPTED MANUSCRIPT}

Table 8. Case study example of protein-based additive risk assessment in new product

\begin{tabular}{|c|c|c|c|}
\hline Ingredients & $\begin{array}{l}\text { Food based } \\
\text { assessment }\end{array}$ & $\begin{array}{c}\text { Protein group based } \\
\text { assessment }\end{array}$ & Action \\
\hline $\begin{array}{l}\text { Chia seeds } \\
\text { (Salvia } \\
\text { hispanica) }\end{array}$ & $\begin{array}{l}\text { No labelling } \\
\text { required }\end{array}$ & $\begin{array}{l}\text { There are still uncertainties with } \\
\text { regard to potential allergenicity } \\
\text { of Chia seeds, however there are } \\
\text { potential cross reactivities for } \\
\text { those with peanut and sesame } \\
\text { allergies (EFSA, 2009) }\end{array}$ & $\begin{array}{l}\text { No labeling required, } \\
\text { but be aware of } \\
\text { potential for } \\
\text { sensitivity if consumer } \\
\text { enquiry }\end{array}$ \\
\hline $\begin{array}{l}\text { Buckwheat } \\
\text { flour } \\
\text { (Fagopyrum } \\
\text { esculentum) }\end{array}$ & $\begin{array}{l}\text { Not one of the } \\
\text { foods requiring } \\
\text { allergen labeling in } \\
\text { EU. Labeling } \\
\text { required if } \\
\text { exporting to Japan } \\
\text { and Korea }\end{array}$ & $\begin{array}{l}\text { Contains prolamin (Fag e 2); } \\
\text { cupin (Fag e } 3)\end{array}$ & $\begin{array}{l}\text { No labeling required } \\
\text { in EU, but required if } \\
\text { exporting to Japan or } \\
\text { Korea. Be aware of } \\
\text { potential for } \\
\text { sensitivity if consumer } \\
\text { enquiry. }\end{array}$ \\
\hline $\begin{array}{l}\text { Dates } \\
\text { (Phoenix } \\
\text { dactylifera) }\end{array}$ & $\begin{array}{l}\text { If dates are } \\
\text { preserved with } \\
\text { sulfur dioxide then } \\
\text { mandatory labeling } \\
\text { of sulfur dioxide } \\
\text { in ingredient list. }\end{array}$ & $\begin{array}{l}\text { Contains profilin (Pho d 2) } \\
\text { (WHO/IUIS, 2014). Date palm } \\
\text { pollen was found to trigger } \\
\text { higher prevalence of asthma and } \\
\text { polysensitisation. Possibility for } \\
\text { presence of unidentified }\end{array}$ & $\begin{array}{l}\text { If preserved with } \\
\text { sulfur dioxide then } \\
\text { mandatory labeling of } \\
\text { sulfur dioxide in } \\
\text { ingredient list. Be } \\
\text { aware of potential for }\end{array}$ \\
\hline
\end{tabular}




\section{ACCEPTED MANUSCRIPT}

\begin{tabular}{|c|c|c|c|}
\hline & & $\begin{array}{l}\text { panallergens (Huertas et al., } \\
\text { 2011). } \\
\text { May cross react with pollens } \\
\text { such as Bermuda grass (Cynodon } \\
\text { dactylon), cultivated rye (Secale } \\
\text { cereale), Timothy grass (Phleum } \\
\text { pratense) ; Sydney golden wattle } \\
\text { (Acacia longifolia) (Kwaasi et } \\
\text { al. } 2002\end{array}$ & $\begin{array}{l}\text { sensitivity if consumer } \\
\text { enquiry. }\end{array}$ \\
\hline $\begin{array}{l}\text { Chocolate } \\
\text { topping }\end{array}$ & $\begin{array}{l}\text { If chocolate } \\
\text { topping contains } \\
\text { lecithin (soy) or } \\
\text { milk then } \\
\text { mandatory labeling } \\
\text { of milk and soy in } \\
\text { ingredient list }\end{array}$ & $\begin{array}{l}\text { Contains phenylethylamine and } \\
\text { theobromine (may result in food } \\
\text { hypersensitivity - e.g. headache) }\end{array}$ & $\begin{array}{l}\text { If chocolate topping } \\
\text { contains lecithin (soy) } \\
\text { or milk then } \\
\text { mandatory labeling of } \\
\text { milk and soy in } \\
\text { ingredient list. Be } \\
\text { aware of potential for } \\
\text { sensitivity if consumer } \\
\text { enquiry. }\end{array}$ \\
\hline
\end{tabular}




\section{ACCEPTED MANUSCRIPT}
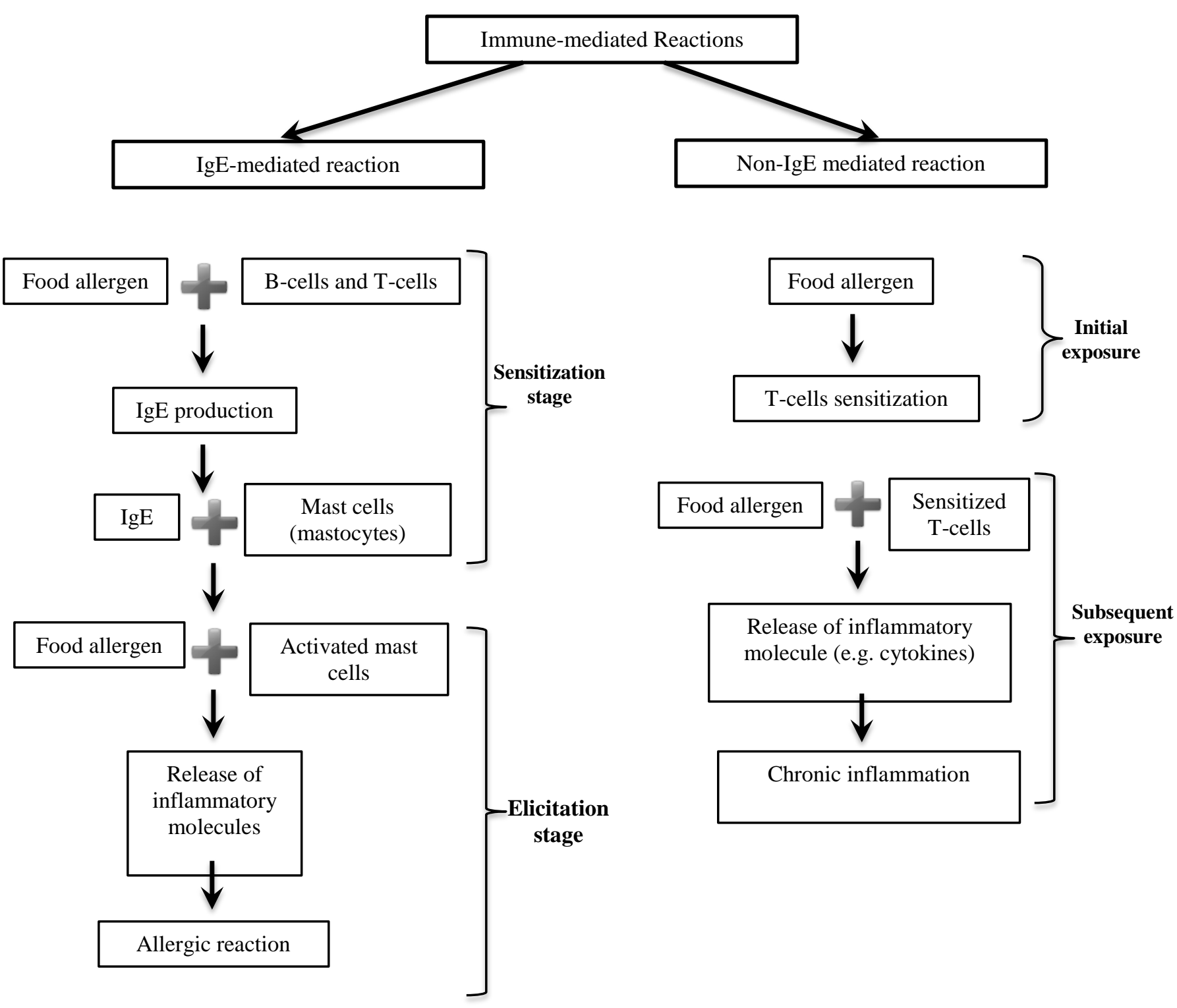

Figure 1. Mechanism of immune mediated allergic reactions (Adapted from FDA, 2015, Venter, 2009) 